\title{
Crónica Judicial de Derecho Eclesiástico en los Estados Unidos de Norteamérica (2015-2017)
}

José Ignacio RuBio LóPEZ

Profesor estable adjunto a cátedra

Universidad Eclesiástica San Dámaso (UESD). Facultad de Derecho Canónico. Madrid orcid 0000-0002-0289-5907

frjoseignaciorubio@gmail.com

SumARIO: I. Crónica judicial de los dos últimos años 2015-2017. II. Salud. III. Matrimonio. IV. Educación. V. RLUIPA. VI. Oraciones legislativas. VII. Libertad de expresión religiosa. VIII. Simbología. IX. Trabajo. X. Ejército. XI. Inmigración y seguridad. XII. Controversias internas. XIII. Privilegio de confidencialidad. XIV. Otros casos. XV. Nuevos tiempos para la libertad primera con Trump y sin Scalia.

$\mathrm{R}$ ecordemos que toda referencia al derecho eclesiástico en los Estados Unidos de Norteamérica debe respetar la estructura federal del país en cada uno de sus tres poderes, judicial, ejecutivo y legislativo ${ }^{1}$. Al ser ésta

\footnotetext{
${ }^{1}$ Así lo hemos venido haciendo desde que abrimos esta sección anual en los números 51 y 52 de Ius Canonicum, en adelante IC. A ella nos remitimos para cuestiones generales que quedaron expuestas entonces para las crónicas siguientes: cfr. J. I. RUBIo LóPEZ, Crónica anual de derecho eclesiástico en los Estados Unidos (2011-2012), Partes I y II, IC 51 (2011) 703-764; IC 52 (2012) 331-374. El examen conjunto de estas memorias (IC 51 [2011] 703-764; IC 52 [2012] 331-374; IC 53 [2012] 737-774; IC 53 [2013] 773-790; IC 55 [2015] 837-913) ofrece un panorama interesante de la evo-
} 
una crónica jurisprudencial, los tiempos vienen marcados por cada año judicial (term) del Tribunal Supremo, la United States Supreme Court, en adelante $\mathrm{USSC}^{2}$, actor principal de esta historia. Nuestro análisis de los últimos dos años comienza así el primer lunes de octubre del 2015 y llega al primer lunes de ese mismo mes del año 2017. En cuanto a su contenido, por tratarse sólo de una memoria, ésta quedará limitada a las cuestiones que estimemos de mayor interés para el derecho de libertad religiosa en función de su novedad, repercusión o trascendencia, contenido y fin.

\section{CRónica JUdiCIAL DE dOS AÑos (2015-2016; 2016-2017)}

A juzgar por los datos ofrecidos a continuación, las controversias sobre libertad religiosa siguen tenido que ver principalmente con el libre ejercicio de la religión (free exercise) de internos en ciertas instituciones, sobre todo en centros penitenciarios. Es decir, el objeto de la segunda cláusula de la ley federal del 2000 Religious Land Use Institutionalized Persons Act, RLUIPA (la sección 3 de la ley). De todos los tribunales, los federales de distrito se siguen llevando el mayor número de los casos.

En el primer año judicial 2015-2016 encontramos, sirviéndonos del buscador jurídico Lexis-Nexis, 664 controversias con referencia a alguna de las cláusulas de libertad religiosa, 431 sobre libre ejercicio y 233 de no establecimiento. Comenzando por la free exercise clause, la inmensa mayoría de ellas (353 de las 431) se plantearon en los tribunales federales de distrito, 27 se sustanciaron en los tribunales federales de apelación (circuitos), una en un tribunal federal de quiebra y otras dos en la USSC (Ben-Levi el 29 de febrero de

lución de la primera de las libertades en Estados Unidos durante la Corte Roberts (2005-). Con ello actualizamos el estudio de esta cuestión ofrecido desde su origen en dos volúmenes: J. I. RUBIO LóPEZ, Hacia la primera libertad. Libertad religiosa en los EE.UU.: de las Colonias a la Corte Rehnquist (1600-1986), Eunsa, Pamplona 2011; IDEM, La primera de las libertades. La libertad religiosa en EE.UU. durante la Corte Rebnquist (1986-2005): una libertad en tensión, Eunsa, Pamplona 2006.

2 Acrónimo preferido aquí al común en Estados Unidos, SCOTUS, Supreme Court of the United States, en http://www.supremecourt.gov/default.aspx. Por otra parte, hasta la fecha no hemos encontrado mejor, más general y rápido acceso al estado de la libertad religiosa en los Estados Unidos que el blog Religion Clause del profesor emérito de la Facultad de Derecho de la Universidad de Toledo (Ohio) Howard Friedman. Este blog cumplió 12 años el 17 de abril de 2017, ha sido muchas veces elegido por el ABA fournal para incluirlo dentro de la lista de los 100 mejores blogs legales y representa un punto de acceso importante para un estudio como el nuestro, cfr. http:// religionclause.blogspot.com.es/ (todas las páginas de internet citadas en esta crónica fueron visitadas en el mes de septiembre del año 2017). 
2016 y Storman's Inc. el 28 de junio de 2016), y las demás en diferentes tribunales de 23 Estados (Alabama, Alaska, California, Connecticut, Florida, Illinois, Indiana, Kansas, Kentucky, Louisiana, Maryland, Massachusetts, Michigan, Minnesota, New Jersey, New York, North Carolina, Ohio, Pennsylvania, Texas, Washington y Wisconsin, amén del District of Columbia). Por su parte, de los litigios en los que se vio afectada la garantía constitucional de no establecimiento (establishment clause), 166 (de los 233 existentes) tuvieron lugar en tribunales federales de distrito y 28 en circuitos de apelación; el resto se planteó en 24 Estados (Arizona, California, Colorado, Connecticut, Delaware, Florida, Illinois, Indiana, Kansas, Kentucky, Maryland, Minnesota, New Jersey, New Mexico, New York, North Carolina, Ohio, Oklahoma, Pennsylvania, Rhode Island, Tennessee, Texas y Washington, así como en el District of Columbia).

Además, los casos que citaron la Religion Freedom Restoration Act (RFRA) de 1993, o alguna de las estatales (state RFRAs), fueron 181. De ellos, 149 se vieron en tribunales federales de distrito, 10 en circuitos de apelación, dos casos en el tribunal federal de quiebra, otros cuatro en otros tribunales federales (US Court of Federal Claims y Court of Appeals for Armed Forces, CAAF) y uno en la USSC (Zubik v. Burwell, el 16 de mayo de 2016). El resto tuvieron lugar en los tribunales estatales de Florida, Illinois, Kentucky, Massachusetts, Maryland, Michigan, New York, Ohio, Pennsylvania y Texas. Finalmente, se plantearon 591 litigios en los que se vio afectada la RLUIPA: 527 en los tribunales federales de distrito, 42 en los circuitos de apelación, uno en la jurisdicción militar (CAAF) y otro más en la USSC (Ben-Levi v. Brown, el 29 de febrero de 2016). A éstos habría que añadir los surgidos en 12 Estados: Arkansas, California, Connecticut, Kentucky, Louisiana, Massachusetts, Maryland, New York, Ohio, Oregon, Pennsylvania y Texas. Si buscamos casos relativos a la sección sobre ordenación urbana de esta ley (zoning law) sólo encontraremos ocho: 5 en tribunales federales de distrito, 2 en los circuitos de apelación y uno en Pennsylvania. Pero, cuando la afectada fue la de los internos en centros penitenciarios (prisons) el número se eleva a 465 controversias: 423 en tribunales federales de distrito, 31 en circuitos de apelación, una en la USSC (Ben-Levi) y las demás en los Estados de California, Kentucky, Louisiana, Massachusetts, Oregon y Texas. Por último, si incluimos las necesidades religiosas de la dieta (religious diet) surgen 78 casos: 74 en tribunales federales de distrito, 3 en circuitos de apelación y uno en Massachusetts; y si añadimos la regulación sobre aseo o aspecto físico (grooming rules) de los presos el balance es de 50 casos: 43 
en tribunales federales de distrito, 6 en circuitos y uno en Oregon. A todo ello habría que añadir los 212 que citaron la Affordable Care Act (ACA) del 2010 (entre ellos los tres de la USSC: Gobeille v. Liberty, el 1 de marzo, Zubik el 16 de mayo y Whole Women's Health v. Hellerstedt, el 27 de junio de 2016), los 125 que trataron el same-sex marriage y las 166 controversias que tuvieron por objeto cuestiones relativas a las así llamadas personas transgénero.

Pasando ahora al segundo año judicial, 2016-2017, de octubre a septiembre de este último año, Lexis-Nexis refiere 535 casos con alusión a alguna de las cláusulas de libertad religiosa, 342 sobre libre ejercicio y 193 de no establecimiento. En relación a la free exercise clause: 284 en los tribunales federales de distrito, 30 en los federales de apelación (circuitos), uno más en la USSC (Trinity Lutheran Church v. Comer, el 26 de junio de 2017) y el resto en diferentes tribunales de 19 Estados (Arizona, California, Connecticut, Florida, Illinois, Indiana, Kansas, Massachusetts, Michigan, Minnesota, New Jersey, New York, North Carolina, Ohio, Oklahoma, Pennsylvania, Washington y Wisconsin, además del District of Columbia). Si vamos al no establecimiento: 121 en tribunales federales de distrito, 38 en circuitos de apelación, dos en la USSC (Trinity Lutheran Church y Trump v. International Refugee, el 26 de junio), uno en el tribunal federal de quiebra y el resto en 21 Estados (California, Connecticut, Florida, Georgia, Illinois, Iowa, Kansas, Kentucky, Massachusetts, Michigan, Minnesota, New York, Oklahoma, Oregon, Pennsylvania, Rhode Island, South Carolina, Texas, Washington, West Virginia y Wyoming). Además la RFRA, la federal y/o las estatales, fue citada en 137 (97 en tribunales federales de distrito y 23 en circuitos de apelación). Por su parte, la RLUIPA fue citada en 552 casos: 488 en los tribunales federales de distrito, 47 en los circuitos de apelación, así como los de los 13 Estados siguientes: Arizona, Arkansas, California, Illinois, Indiana, Michigan, New York, Ohio, Oklahoma, Oregon, Pennsylvania, Tennessee y Texas. De todos esos casos, 11 tuvieron por objeto la sección sobre regulación del suelo de esta ley (apreciando su lento descenso): 8 en tribunales federales de distrito, 2 en los circuitos de apelación y uno más en New York. Por su parte, la situación de los internos en centros penitenciarios apareció en 427 casos (confirmando así su paulatino ascenso): 383 en tribunales federales de distrito, 35 en circuitos de apelación y los estatales de California, Indiana, Pennsylvania, Oregon y Tennessee. De ellos, 76 casos comprendieron las necesidades religiosas de la dieta (religious diet): 75 en tribunales federales de distrito y uno en circuitos de apelación. Las controversias sobre aseo de los presos llegaron a 42: 35 en tribunales federa- 
les de distrito, 5 más en circuitos y dos en los tribunales estatales de Oregon y Tennessee. Finalmente, por completar el cuadro de este año, 228 sentencias incluyeron en sus textos la ACA del 2010, 102 más trataron el same-sex marriage y 194 se ocuparon de la cuestión polémica de los transgénero.

Como es imposible ofrecer una relación completa de este tipo de casos cuando, como aquí, no se pretende más que la crónica de los dos últimos años, por el momento, a la espera de un estudio más reposado de la cuestión sobre la Corte Roberts ${ }^{3}$, nos contentaremos con indicar los casos resueltos por la USSC, tanto a través de sus fallos como de ciertos recursos rechazados en los últimos veinticuatro meses. Las apelaciones (writs of certiorari) no admitidas, en casos directa o indirectamente relacionados con el derecho de libertad religiosa, fueron 28: 17 en el año judicial 2015-2016 y las 11 restantes en el siguiente $^{4}$. Cinco vinieron del noveno circuito y tres más del décimo; dos del

${ }^{3}$ El Chief fustice John G. Roberts Jr. accedió a la presidencia de la USSC el 29 de septiembre del año 2005. Entre los jueces que componían entonces el Tribunal, se encontraban los conservadores Antonin Scalia (septiembre de 1986) y Clarence Thomas (octubre de 1991), los liberales Ruth Bader Ginsburg (agosto de 1993) y Stephen G. Breyer (agosto de 1994), y el «centrista» Anthony M. Kennedy (febrero de 1988). Pocos meses después de Roberts, el 31 de enero del 2006, Samuel Anthony Alito llegó al Tribunal nominado por el presidente George W. Bush. Se incorporó al ala conservadora del Supremo. Los siguientes en llegar vinieron de la mano de Obama, las liberales Sonia Sotomayor (agosto de 2009) y Elena Kagan (agosto de 2010). El Tribunal quedó dividido entonces en dos bloques: el conservador con Roberts, Alito, Scalia y Thomas; y el liberal con Ginsburg, Breyer, Sotomayor y Kagan. De este modo fue resultando decisiva la posición del juez Kennedy que fue inclinando la balanza 5-4 del lado liberal. Pero el 13 de febrero de 2016 murió repentinamente Antonin Scalia siendo sustituido por el juez federal del décimo circuito Neil McGill Gorsuch, tras su nominación por el presidente Trump el 31 de enero de 2017. Y así, aunque en conjunto puede afirmarse que la Corte Roberts ha sido hasta ahora un tribunal moderadamente conservador, en el año judicial 2014-2015 se inclinó del lado liberal al respaldar la Affordable Care Act (ACA) de Obama (King v. Burwell) o al reconocer el same-sex marriage (Obergefell v. Hodges) como un derecho amparado en la Decimocuarta Enmienda, no obstante sus decisiones conservadoras sobre la pena de muerte (Glossip v. Gross) o la protección medioambiental (Michigan v. EPA). El desmarque de Roberts en el caso planteado sobre la ACA (King) hace del juez Alito, tal vez, el más conservador de los jueces, al no haberse alineado hasta el presente con el ala liberal. Desde entonces, la USSC ha mantenido esa dirección. Aún es pronto para ofrecer una imagen de Gorsuch en el Tribunal, juez sobre el que volveremos más adelante.

${ }^{4}$ En el año judicial 2015-2016: Phillips v. New York, 136 S.Ct. 104 (October 5, 2015); Sac and Fox Nation of Oklahoma v. Thorpe, 136 S.Ct. 84 (October 5, 2015); Center for Competitive Politics v. Harris, 136 S.Ct. 480 (November 9, 2013); Cutler v. Department of Health and Human Services, 136 S.Ct. 877 (January 11, 2016); Stenehjem v. MKB Management Corp, 136 S.Ct. 981 (January 25, 2016); Ben-Levi v. Brown, 136 S.Ct. 930 (February 29, 2016); Doe v. Christie, 136 S.Ct. 1155 (February 29, 2016); American Freedom Defense Initiative v. King County, Washington, 136 S.Ct. 1022 (March 7, 2016); Cressman v. Thompson, 136 S.Ct. 1452 (March 21, 2016); Knight v. Thompson, 136 S.Ct. 1824 (May 2, 2016); Wayne County v. Bible Believers, 136 S.Ct. 2013 (May 16, 2016); Rogers v. Roman Catholic Archbishop of Boston, 136 S.Ct. 2013 (May 16, 2016); Chabad-Lubavitch of 
tercero, otros dos del quinto y dos más del sexto; y uno de cada uno de los circuitos siguientes: segundo, cuarto, séptimo, octavo, undécimo, y para el Distrito de Columbia. Un caso le llegó a la USSC del circuito federal y otro de la jurisdicción militar. Los restantes fueron en apelación de sentencias de tribunales estatales de Maryland, Massachusetts, Michigan, Minnesota y New York. El repaso de todos estos recursos revela la evolución de la jurisprudencia federal y estatal en nuestra materia, al tiempo que ofrecen una interesante radiografía de las controversias sociales, culturales y religiosas que se han ido desarrollando en los Estados Unidos durante estos últimos años y que van desde la cobertura de seguro médico de la «Obamacare» con la polémica surgida por la inclusión de material contraceptivo, a los matrimonios entre personas del mismo sexo y su validez en los Estados, pasando por esa terapia sobre cambio de orientación sexual en menores de 18 años, oraciones en cuerpos legislativos, adaptaciones religiosas como el uso de prendas en el trabajo o de barba en centros penitenciarios, asistencia financiera en escuela religiosa o exenciones fiscales en planes de pensiones, garantías procesales incluyendo medidas sobre honorarios de abogados, discriminación por razón de orientación sexual en establecimientos públicos, o libertad de expresión en asuntos religiosos.

En los dos años judiciales que nos ocupan, la USSC ha resuelto controversias que, por importantes que sean, sólo afectan tangencial o marginalmente al derecho de libertad religiosa. Así, por ejemplo, el alto tribunal ha querido garantizar la defensa de los derechos civiles federalmente reconocidos tanto en los tribunales estatales como en los federales aplicando en unos y otros las mismas reglas sobre los honorarios de los abogados (Fames v. City of Boise, el 25 de enero de 2016, y CRST Van Expedited Inc. v. EEOC, el 19 de

\footnotetext{
Michigan v. Schuchman, 136 S.Ct. 2449 (May 23, 2016); Sunrise Children's Services Inc. v. Glisson, 134 S.Ct. 2449 (May 23, 2016); Storman's Inc. v. Wiesman, 136 S.Ct. 2433 (June 28, 2016); Currier v. Fackson Women's Health Organization, 136 S.Ct. 2536 (June 28, 2016); Schimel v. Planned Parenthood of Wisconsin, 136 S.Ct. 2545 (June 28, 2016). Y en el año judicial 2016-2017: Klingenscbmitt v. United States, 137 S.Ct. 93 (October 3, 2016); Melhorn v. Baltimore-Washington Conference of the United Methodist Church, 137 S.Ct. 377 (October 31, 2016); Payne v. University of Southern Mississippi, 137 S.Ct. 475 (November 14, 2016); COPE v. Kansas State Board of Education, 137 S.Ct. 475 (November 14, 2016); Pfeil v. St. Matthews Evangelical Lutheran Church, 137 S.Ct. 493 (November 28, 2016); Oklevueha Native American Church of Hawaii v. Lynch, 137 S.Ct. 510 (November 28, 2014); Tung v. China Buddhist Association, 137 S.Ct. 628 (January 9, 2017); Brown v. Bubman, 137 S.Ct. 828 (January 23, 2017); Evangelical Lutheran Church in America v. Bacon, 137 S.Ct. 1213 (February 27, 2017); Welch v. Brown, 137 S.Ct. 2093 (May 1, 2017); y Sterling v. United States, 137 S.Ct. 2212 (June 5, 2017).
} 
mayo de 2016). Y cuando volvió a planteársele la oportunidad de entrar en la cuestión de la cobertura de material contraceptivo exigida por la ACA, en relación a organizaciones religiosas no lucrativas, el Supremo anuló las decisiones recurridas y reenvió los casos a los tribunales de procedencia (Zubik v. Burwell). Esto mismo hizo en el caso del acceso a los baños por menores con problemas de identidad de género, tras el cambio de normativa en el Departamento de Educación por la administración Trump (Gloucester County $v$. G.G., el 6 de marzo de 2017). Más decidida se mostró la USSC cuando anuló una ley de Texas que restringía el aborto (Whole Women's Health) o se pronunció a favor de la consideración como «eclesiales», bajo una ley federal (ERISA), de aquellos planes de pensiones ofrecidos no por Iglesias sino por hospitales afiliados religiosamente a organizaciones eclesiales, a fin de poder beneficiarse de sus exenciones (Advocate Health Care Network v. Stapleton, el 5 de junio de 2017). El Supremo apostó también por la libertad de expresión, aunque su contenido pudiera resultar ofensivo, en un caso de registro de marcas (Matal v. Tam, el 19 de junio de 2017), así como por la igualdad de trato en un caso de certificado de nacimiento para personas casadas del mismo sexo (Pavan v. Smith, el 26 de junio de 2017). Con todo, los dos casos que más trascendencia mediática y repercusiones futuras pueden tener son los que resolvió en este último año al permitir ayudas públicas en una escuela religiosa por la garantía de libre ejercicio religioso sin violación del no establecimiento (Trinity Lutheran (hurch) e intervenir en el asunto de las órdenes presidenciales restrictivas sobre entrada de nacionales de seis países mayoritariamente musulmanes ante las cuestiones de establecimiento religioso que pudieran estar implicadas en ellas (Trump v. International Refugee y Trump v. Hawaii). En todo caso, y al margen de su mayor o menor importancia, puesto que una crónica no es terreno propicio para comentar sentencias, nos limitaremos aquí a dejar constancia de ellas por materias e incluiremos también alguna que otra controversia de interés en la jurisdicción federal o estatal.

\section{SALUD}

Zubik v. Burwell, 136 S.Ct. 1557 (2016). El 6 de noviembre de 2015 la USSC garantizó el recurso de apelación que se le presentó en una serie de casos en los que organizaciones religiosas sin ánimo de lucro (hospitales, universidades o iniciativas asistenciales o caritativas), todas contrarias, por razones de conciencia, a la exigencia de cobertura de material contraceptivo de 
la $\mathrm{ACA}^{5}$, habían denunciado la adaptación religiosa ofrecida por la administración Obama. Y es que la respuesta ofrecida por el gobierno, intentando encontrar una salida para que pudieran ejercer su objeción religiosa, seguía colocando a esas organizaciones ante un grave dilema moral que quedó espléndidamente trazado en el escrito presentado, entre otros, por la Conferencia episcopal de los Estados Unidos. Después de afirmar el poderoso interés público en la viabilidad y continuidad de las FBOs (es decir, «faith-based organizations»), en serio peligro como consecuencia de las sanciones a las que se enfrentarían de no cumplir con aquello que su conciencia no permitía ${ }^{6}$, así como de su contribución al bien común, los obispos católicos quisieron ir al fondo del asunto. Frente al intento de banalización del acto exigido, el problema que planteaba el ejercicio de la adaptación religiosa no era el de rellenar un simple impreso o notificar una situación para poder acogerse a la exención. La historia de los mártires estaba llena de ejemplos en los que los creyentes habían ido a la muerte por negarse a decir unas palabras, firmar un papel o realizar cualquier otro acto contrario a su conciencia, desde San Policarpo de Esmirna ante el emperador a Santo Tomás Moro ante el rey Enrique VIII, pasando por la historia de Eleazar en el libro de los Macabeos ${ }^{7}$. El problema nunca había sido lo que podía o no podía hacer el gobierno, sino lo que a ellos se les exigía, algo que no les era permitido hacer en conciencia porque se harían cómplices, cooperadores materiales, de un grave pecado con conse-

\footnotetext{
${ }^{5}$ La Patient Protection and Affordable Care Act (PPACA) del 2010, comúnmente conocida como Affordable Care Act (ACA) u «Obamacare», apelación despectiva de sus detractores, fue firmada por Obama el 23 de marzo del 2010. Esta ley quiso extender la cobertura del seguro de salud a un mayor número de personas imponiendo la obligación individual (individual mandate) de un «mínimo esencial» del seguro de salud para muchos americanos. La USSC respaldó la ley en $\mathrm{Na}$ tional Federation of Independent Business v. Sebelius, 132 S.Ct. 2566 (June 28, 2012). El caso es que, aun manteniendo su validez, muchos flecos quedaban pendientes, por lo que el Supremo habría de volver sobre ella sin tardar mucho para resolver dos cuestiones: la objeción de conciencia de empresarios que no quieren incluir cierto material contraceptivo en el seguro por razones religiosas (el Supremo garantizó esa objeción en Burwell v. Hobby Lobby Stores, Inc., 134 S.Ct. 2751 [2014]), algo que llevó a la administración Obama -a través de tres agencias o departamentos: el Department of Health and Human Services (HHS), el Internal Revenue Service (IRS), y el Employee Benefits Security Administration (EBSA)- a seguir trabajando en el capítulo de la adaptación religiosa); o, el alcance de la ayuda federal a los Estados que la USSC dejó resuelto en King v. Burwell, 135 S.Ct. 2480 (2015), como vimos en la crónica pasada y a la que nos remitimos hasta en este punto.

${ }^{6}$ Cfr. Brief Amicus Curiae of United States Conference of Catholic Bishops et al in Support of Petitioners and Supporting Reversal, January 11, 2016, en http://www.scotusblog.com/wp-content/uploads/2016/01/Zubik-USCCB-brief.pdf, pp. 9-10.

Cfr. ibid., 27 y ss.
} 
cuencias inmediatas en el presente y nefastas para la vida eterna. La mima cuestión de ahora como la de entonces era o la obediencia a la conciencia o cargar con sanciones de millones de dólares.

El Supremo, al aceptar el recurso en Zubik, lo limitó a la cuestión acerca de si la normativa denunciada ofendía o no el derecho al libre ejercicio religioso de esas organizaciones según la Religious Freedom Restoration Act de 1993. Los siete casos llegaron del tercer circuito (Zubik v. Burwell y Geneva College v. Burwell), del quinto (East Texas Baptist University v. Burwell), del décimo (Little Sisters of the Poor v. Burwell y Southern Nazarene University v. Burwell), así como del circuito para el Distrito de Columbia (Priests for Life v. Department of Health \& Human Services y Roman Catholic Archbishop v. Burwell) ${ }^{8}$. Todos ellos habían mantenido como válida la adaptación religiosa ofrecida por la administración, a diferencia de otros dos casos del octavo circuito en los que este tribunal sí se había manifestado en contra de ella como una violación de la RFRA (Sharpe Holdings, Inc. v. U.S. Department of Health and Human Services y Dordt College v. Burwell) 9 . La discusión del caso tuvo lugar el 23 de marzo de 2016, un mes después de la muerte inesperada del juez Scalia. Una semana más tarde, el 29 de marzo, la USSC solicitó a las partes el envío de escritos adicionales que explicaran cómo las exigencias del contraceptive mandate pudieran ser cumplidas respetando al mismo tiempo las objeciones religiosas de los demandantes, sin verse implicados en nada más que su propia decisión de ofrecer cobertura sanitaria sin esos productos o servicios contraceptivos. Parecía que lo creía posible cuando se aventuró a ofrecerles un ejemplo de ello. Las partes respondieron en sendos escritos que le hicieron llegar al Tribunal los días 12 y 20 de abril, evidenciando en el contenido su falta de acuerdo, aunque de algún modo sí se percibía un cierto avance. Con todo, el gobierno seguía pensando que la exención pedida suponía una carga excesiva y las demandantes no veían más camino que el de la adaptación para proteger su conciencia. Una y otras se exponían así a una decisión del Tribunal si consiguiera los votos suficientes en uno u otro sentido, lo que no parecía previsible. Y la respuesta esperada llegó por fin el 16 de mayo, en Zubik v. Burwell, una sentencia per curiam que anuló sin más los juicios de los circuitos tercero, quinto, décimo y del Distrito de Columbia, reenviando los

\footnotetext{
${ }^{8}$ Cfr. Geneva College v. Burwell, 778 F.3d 422 (3rd Cir. 2015); East Texas Baptist University v. Burwell, 793 F.3d 449 (5th Cir. 2015); Little Sisters of the Poor v. Burwell, 794 F.3d 1151 (10th Cir. 2015); y Priests for Life v. Department of Health \& Human Services, 772 F.3d 229 (DC Cir. 2014).

${ }^{9}$ Cfr. Sharpe Holdings, Inc. v. U.S. Department of Health and Human Services, 801 F.3d 927 (8th Cir. 2015) y Dordt College v. Burwell, 801 F.3d 946 (8th Cir. 2015).
} 
casos a estos tribunales y pidiendo que fueran resueltos de modo consistente con esta opinión. La sentencia, sin entrar en el fondo del asunto, pidió a la administración que siguiera trabajando en la línea de ofrecer a las organizaciones religiosas un modelo que respetara su libre ejercicio religioso, eso sí, quedando también garantizado el igual acceso de las mujeres al material contraceptivo. Una semana después, el Tribunal Supremo insistía en lo mismo: a través de dos órdenes GVR («granted-vacated-remanded»), aceptaba el recurso presentado en un par de casos similares a Zubik, anulaba las decisiones recurridas, y enviaba los casos al segundo (Catholic Health Care System) y sexto circuito (Michigan Catbolic Conference) para que fuera resuelta la objeción de esas organizaciones religiosas no lucrativas al mandato de contracepción según lo indicado en $Z u$ $b i k^{10}$. Por su parte, la respuesta del gobierno a esta sentencia llegó el 22 de julio cuando las tres agencias federales implicadas en este asunto, el HHS, el IRS, y la EBSA, respetando lo dispuesto por el Supremo en Zubik, a través de un texto publicado en «Federal Register»y a fin de elaborar unas reglas finales sobre esta cuestión, pidieron les fueran remitidas antes del 20 de septiembre sugerencias sobre cómo ajustar las objeciones de conciencia de las organizaciones elegibles a la cobertura de servicios de contracepción ${ }^{11}$. Los comentarios superaban los 50.000 en las primeras semanas de enero de 2017 y la administración tuvo que reconocer su incapacidad de resolver la cuestión. Ya con Trump en la Casa Blanca, el Departamento de Justicia pidió en abril más tiempo, el 4 de mayo firmó el presidente una orden ejecutiva para que las agencias implicadas de su administración enfrentaran la solución al problema de conciencia que planteaba la adaptación existente y el 23 de ese mes se publicó un texto provisional de 125 páginas ${ }^{12}$. Y el 6 de octubre la administración Trump, fiel al com-

${ }^{10}$ Cfr. Catholic Health Care System v. Burwell, 136 S.Ct. 2450 (May 23, 2016). El caso venía del segundo circuito que había anulado la decisión de primera instancia favorable a las organizaciones religiosas al creer que el mandato limitaba sustancialmente el libre ejercicio religioso de estas entidades en contra de la RFRA: Catholic Health Care System v. Burwell, 796 F.3d 207, at 209-210 [Pooler, J.] (2nd Cir., August 7, 2015). El otro caso era Michigan Catbolic Conference v. Burwell, 136 S.Ct. 2450 (May 23, 2016), pronunciándose el Supremo aquí en los mismos términos que antes. En este caso una sentencia del sexto circuito que confirmaba la decisión recurrida sin ver ninguna violación de la RFRA: Mich. Catholic Conf. \& Catholic Family Servs. v. Burwell, 807 F.3d 738, at 740-741 [Moore, J.] (6th Cir., August 21, 2015).

${ }^{11}$ Cfr. Department of the Treasury, IRS, Department of Labor, EBSA, Department of Health and Human Services, Coverage for Contraceptive Services, 81 Fed. Reg. 47741 (July 22, 2016), en https://www.gpo.gov/fdsys/pkg/FR-2016-07-22/pdf/2016-17242.pdf.

${ }^{12}$ Cfr. https://www.documentcloud.org/documents/3761268-Preventive-Services-Final-Rule0.html. 
promiso adquirido, aprobó finalmente unas nuevas reglas, concediendo directamente la objeción de conciencia al mandato contraceptivo de la ACA por razones religiosas y morales. Pero es que, pocos días después, el 12 de octubre, el presidente firmó un Memorándum promoviendo la elección del consumidor en el campo de la salud, un duro golpe a la viabilidad de la ACA. Dos fuentes de controversias futuras.

El 11 de enero de 2016 la USSC, en Cutler v. Department of Health and Human Services, 136 S.Ct. 877 (2016), no quiso entrar en un caso en el que el circuito del Distrito de Columbia había rechazado la pretensión de inconstitucionalidad, como algo contrario a la debida sepración exigida por la garantía de no establecimiento religioso, de la excepción religiosa al mandato individual de la ACA para miembros de ciertos tradicionales grupos religiosos como los amish o los menonitas ${ }^{13}$. Y el 4 de agosto de 2017 el tercer circuito, en Real Alternatives Inc. v. Secretary Department of HHS, 2017 U.S. App. LEXIS 14361 (3rd Cir., 2007), rechazó la denuncia de discriminación por el trato excepcional concedido a las organizaciones religiosas sin ánimo de lucro.

Stormans Inc. v. Wiesman, 136 S.Ct. 2433 (2016). El 28 de junio de 2016 la USSC no quiso entrar en un recurso de apelación que se le presentó frente a una sentencia del noveno circuito que había resuelto a favor de una comisión estatal de Washington («Washington Pharmacy Quality Assurance Commission») que sólo había permitido una adaptación religiosa limitada para farmacéuticos que objetaran a la entrega de píldoras contraceptivas del día después. La objeción de conciencia no se aplicaría a las farmacias pues pesaba sobre todas la obligación de dispensar ese fármaco, aunque el dueño no quisiera por esa clase de razones. Sin embargo, un farmacéutico lo que sí que podría, por su conciencia religiosa, era negarse a entregarlo siempre que en ese establecimiento hubiera otro para hacerlo ${ }^{14}$. Aunque el Supremo rechazó el recurso planteado, el juez Alito no desaprovechó la oportunidad de manifestar su desacuerdo en una opinión disidente a la que se sumaron el Chief Justice Roberts y el juez Thomas. Para Alito estábamos ante un caso claro de hostilidad hacia las creencias cristianas contrarias al aborto y contracepción del titular de la farmacia ${ }^{15}$.

${ }^{13}$ Cfr. Cutler v. United States HHS, 797 F.3d 1173 (D.C. Cir., August 14, 2015).

${ }^{14}$ Cfr. Stormans Inc. v. Wiesman, 794 F.3d 1064 (9th Cir., July 23, 2015).

15 Cfr. Stormans Inc. v. Wiesman, 136 S.Ct. 2433, at 2433; 2440 [Alito, J., dissenting] (2016). 
Chamorro v. Dignity Health, Case CGC 15-549626 (CA Super., January 14, 2016). En este otro caso de objeción de conciencia en materia sanitaria, un tribunal estatal de California falló a favor de un hospital católico que, fiel a sus creencias, no deseaba practicar a las mujeres ligaduras de trompas por razones contraceptivas. Desde los años 70 del pasado siglo la Conferencia norteamericana de obispos católicos había ido respondiendo a ciertos desafíos éticos en el área de la salud a través de unas directrices aprobadas por su comité de doctrina, la quinta edición en 2009: Ethical and Religious Directives for Catholic Health Care Services ${ }^{16}$. La demandante en este caso era una mujer de 33 años, Rebecca Chamorro, que pedía al tribunal una orden que obligara al hospital católico a realizar esa operación pues, así entendía, lo contrario supondría una discriminación de género prohibida por la Constitución estatal. El tribunal concluyó que la política del hospital operaba igual para hombres que para mujeres, negándose a la esterilización en ambos $\operatorname{casos}^{17}$.

Means v. U.S. Conference of Catholic Bishops, 836 F.3d 643 (6th Cir., Sept. $8,2016)$. Una mujer embarazada de cuatro meses y medio denunció al hospital católico y a la Conferencia de obispos por las directrices dadas en la materia, al no haberle ofrecido la oportunidad de terminar su embarazo a pesar de la seria infección que le hubiera podido causar infertilidad e incluso su muerte. El sexto circuito desestimó aquí la denuncia frente a la USCCB, dudó que existiera un deber por parte de la Conferencia y de los hospitales de actuar en contra de sus creencias religiosas pero, aun existiendo esa obligación, en el litigio la demandante no había probado la presencia de un daño físico actual que el derecho de Michigan exigía en los casos de responsabilidad por una acción negligente.

Stenehjem v. MKB Management Corp., 136 S.Ct. 981 (2016). El 25 de enero de 2016 el Supremo negó el recurso de apelación que se le presentó contra una decisión del octavo circuito que declaró inconstitucional una ley de North

${ }^{16}$ Cfr. United States Conference of Catholic Bishops, Ethical and Religious Directives for Catholic Health Care Services, Fith Edition, en http://www.usccb.org/issues-and-action/humanlife-and-dignity/health-care/upload/Ethical-Religious-Directives-Catholic-Health-Care-Services-fifth-edition-2009.pdf.

${ }^{17}$ Puede accederse a la historia del caso en la página web de la ACLU del Norte de California que es lq que asistió legalmente a la mujer: https://www.aclunc.org/our-work/legal-docket/chamorro-v-dignity-health-religious-refusals. 
Dakota prohibiendo el aborto a partir del momento en el que es detectable el latido cardíaco del feto ${ }^{18}$.

Whole Woman's Health v. Hellerstedt, 136 S.Ct. 2292 (2016). El 13 de noviembre de 2015 la USSC aceptó a trámite el recurso planteado frente a una ley de Texas que, al regular las condiciones en las clínicas donde se realizaban abortos (que los médicos pudieran acudir a hospitales cercanos o que esas clínicas cumplieran con los requisitos propios de todo centro quirúrgico ambulatorio), podría poner en riesgo el ejercicio de ese derecho al aborto ante el cierre de muchas de esas clínicas. La discusión del caso tuvo lugar el 2 de marzo y la respuesta de la USSC llegó el 27 de junio cuando anuló la ley estatal en una decisión 5 a 3. La opinión mayoritaria corrió a cargo del juez Breyer calificando la normativa de obstáculo sustancial para el libre acceso de la mujer al aborto. Los jueces Kennedy, Ginsburg, Sotomayor y Kagan lo suscribieron. El juez Alito ofreció una opinión disidente a la que el Chief Justice Roberts y el juez Thomas se sumaron. Pero el Estado de Texas no fue el único que había legislado restrictivamente en la materia. Cuando le llegaron al Supremo otras dos leyes similares de Mississippi y Wisconsin, la USSC rechazó al día siguiente, el 28 de junio, el recurso planteado ${ }^{19}$.

Foothill Church v. Rouillard, 2017 U.S. Dist. LEXIS 142325 (ED CA., Sept. 1, 2017). Un tribunal federal de distrito de California falló en contra de la pretensión de tres iglesias que pedían respetar planes de salud para sus empleados conformes a sus creencias religiosas, excluyendo de ellos el aborto. El departamento estatal de salud había enviado en agosto del 2014 una serie de cartas que exigía a siete aseguradoras privadas eliminar de sus pólizas toda cláusula que excluyera o limitara esa clase de servicios. Este tribunal federal había descartado en julio del año anterior las peticiones que se le habían hecho por las garantías de no establecimiento y de libertad de expresión, dejando a salvo para su examen las de libre ejercicio de la religión e igual protección ${ }^{20}$. Ahora resolvió que las cartas eran de neutral y de general aplicación sin verse afectadas, por ello, las garantías de libre ejercicio o de igualdad.

${ }^{18}$ Cfr. MKB Mgmt. Corp. v. Stenehjem, 795 F.3d 768 (8th Cir., July 22, 2015).

${ }^{19}$ Cfr. Currier v. Jackson Women's Health Organization, 136 S.Ct. 2536 (2016); Jackson Women's Health Organization v. Currier, 760 F.3d 448 (5th Cir., July 29, 2014). Y Schimel v. Planned Parenthood of Wisconsin, 136 S.Ct. 2545 (2016); Planned Parenthood of Wisconsin v. Schimel, 806 F.3d 908 (7th Cir., November 23, 2015).

${ }^{20}$ Cfr. Foothill Church v. Rouillard, 2016 U.S. Dist. LEXIS 89678 (ED CA., July 11, 2016). 
Phillips v. New York, 136 S.Ct. 104 (2015). El 5 de octubre de 2015, la USSC no quiso entrar en un recurso que le llegó del segundo circuito en el que este tribunal, confirmando la sentencia recurrida, había respaldado la exigencia de New York (N.Y. Pub. Health Law $\$ 2164[7][a])$ sobre vacunación obligatoria de los niños en las escuelas públicas; la normativa contemplaba la posilidad de excepciones por razones médicas o religiosas, así como de ausencias, autorizadas por los funcionarios, de los alumnos exentos de vacunación durante el tiempo del brote de la enfermedad prevenible por esa vacuna ${ }^{21}$. En este caso, unos padres católicos (a dos de ellos sí se les había concedido la objeción religiosa solicitada y enviado a los menores a casa durante un episodio de varicela, mientras que al tercero -también católico- se le había denegado) juzgaban que la regulación estatal contravenía las garantías de igual protección, libre ejercicio, proceso justo, así como de la Novena Enmienda. En realidad, las controversias sobre la exigencia de vacunación forman parte de un capítulo que ha ido en aumento, a juzgar por los casos siguientes.

Watkins-El v. Department of Education, 2016 U.S. Dist. LEXIS 139860 (ED NY, Oct. 7, 2016). En esta ocasión, el tribunal negó que las objeciones morales, no propiamente religiosas, estuvieran incluidas dentro de la exención exclusivamente religiosa a la exigencia de vacunación escolar contemplada en la legislación estatal de New York. En este caso unos padres musulmanes -con creencias islámicas Moor- no habían podido demostrar que sus objeciones a la vacunación de sus hijos escolarizados en Queens, por contenerse en esas vacunas ciertas sustancias que no podían consumir, fueran exigencias de su fe.

Flynn v. Estevez, 221 So. 3d 1238 (Fl App., June 27, 2017). Este tribunal estatal de Florida sostuvo aquí que una escuela católica si podía exigir la vacunación a todos los alumnos del centro, a pesar de las objeciones religiosas que se pudieran presentar. El argumento para ello fue la doctrina de la autonomía de la iglesia, algo que impide al tribunal civil entrar a definir el catolicismo a fin de precisar si la política del centro escolar era o no conforme a los principios de esa creencia.

In the Interest of M.H.D., K.S.D., and O.H.D., Case No. 116, 821 (KA App., July 14, 2017). En este caso, un tribunal estatal de primera instancia en

${ }^{21}$ Cfr. Phillips v. City of New York, 775 F.3d 538 (2nd Cir., January 7, 2015). 
Kansas había privado temporalmente de la custodia de sus hijos a una madre y resuelto que los menores fueran vacunados. La madre presentó entonces sus objeciones religiosas, dándole el tribunal el tiempo oportuno para presentar sus alegaciones, tras lo cual decidió seguir adelante con la vacunación. Fue entonces cuando la madre apeló la decisión del tribunal y ahora el de apelaciones rechazó su competencia ${ }^{22}$.

In Re the Paternity of: G.G.B.W., a Minor Child, 7.B. v. S.W., Case No. 49A04-1611-JP-2474 (IN App., July 26, 2017). En este caso, el tribunal estatal de Indiana falló a favor del convenio regulador de divorcio por encima de la ley estatal sobre vacunación de Indiana. El matrimonio en ese convenio había dispuesto que si fuera exigida la vacunación de los menores, para poder entrar en una escuela, se procediera a ella. La madre, cuando llegó el caso, se opuso a la vacunación de su hija por razones religiosas, acogiéndose a la objeción prevista por la ley de ese Estado. Sin embargo, el padre sí deseaba que la menor fuera vacunada a fin de evitar el riesgo que supondría para los hermanos menores. El tribunal dio la razón al padre, resolviendo a favor de la cláusula del convenio ${ }^{23}$.

In Re Elianah T.-T., 326 Conn. 614 (CT Sup. Ct., Aug. 15, 2017). Aquí el tribunal Supremo de Connectcut anuló el fallo recurrido y dijo que el Estado ( «Commissioner of Children and Families») no podía imponer la vacunación de aquellos menores en custodia temporal cuandos sus padres hubieran manifestado objeciones a ella, en este caso por razones religiosas. Las vacunas, ausente un daño, enfermedad o lesión, no eran tratamiento médico sino preventivo.

Nikolao v. Lyon, 238 F. Supp. 3d 964 (ED MI, Feb. 23, 2017). En esta ocasión una madre católica de cuatro hijos en edad escolar en un condado de $\mathrm{Mi}$ chigan que no quería, por razones religiosas, vacunarlos, interpuso una denuncia contra el departamento de salud, cuando consideró que el modo como se accedía a la objeción solicitada había violado su derecho al libre ejercicio religioso y había supuesto una vulneración de la garantía constitucional de no

${ }^{22}$ Cfr. http://www.kscourts.org/Cases-and-Opinions/Opinions/Unpublished/Ctapp/2017/20170714/ 116821.pdf.

${ }^{23}$ Cfr. http://www.in.gov/judiciary/opinions/pdf/07261701mlb.pdf. 
establecimiento. Una normativa estatal del 2014 exigía, por razones de información y para poder acogerse a esa clase de objeción religiosa, que la solicitante expusiera ante una enfermera la religión que profesaba, así como sus objeciones, entrando en una discusión sobre los beneficios o riesgos que esto supondría para la salud de los menores. En este sentido, el departamento de salud había elaborado una serie de materiales para que los funcionarios pudieran disuadir a los padres de esa decisión, e incluso para contra argumentar las posibles objeciones religiosas que se pudieran plantear. Pues bien, en esas conversaciones con el personal del departamento, se vertiron, según la demandante, mentiras acerca de su fe católica y de declaraciones del Papa. Al final sí se le concedió la objeción pedida pero no por razones religiosas, sino por otro tipo, también permitido en la ley. El tribunal federal de distrito, en contra de las pretensiones de la demandante, negó que la madre hubiera sido forzada a tomar una decisión en contra de sus creencias, por muy desagradable que le pudiera haber resultado o por las mentiras vertidas a su parecer durante el proceso seguido, siendo así que la normativa no desfavorecía ni una ni todas las religiones, sin tener, como principal efecto, el avance o no de la religión.

Magazu v. Department of Children and Families, 473 Mass. 430 (MA Sup. Jud. Ct., Jan. 4, 2016). En este caso, una agencia negó la acogida y/o adopción de unos niños a una pareja cristiana que empleaba el castigo corporal como forma de disciplina. La normativa estatal prohibía esa clase de corrección sobre los menores acogidos o adoptados. Los padres aceptaron esa condición aunque no excluyeron la posibilidad de azotes o medidas similares en la educación de sus propias hijas naturales. Esto fue lo que provocó el rechazo de su solicitud y los padres lo denunciaron como violación del libre ejercicio de su religión. El tribunal aquí entendió que el límite sustancial sobre las creencias religiosas de la familia quedaba justificado por la presencia de un poderoso interés público como era la protección del bienestar físico y emocional de los menores. Meses después, un tribunal estatal de apelación de Wisconsin, en State of Wisconsin v. Caminiti, 369 Wis. 2d 223 (WI App., April 7, 2016), condenó a unos padres cristianos que castigaban a sus hijos como abuso físico intencionado, sin que esa prohibición pudiera interferir con los derechos de conciencia y libre ejercicio religioso.

State of Oregon v. Hickman, 358 P.3d 987 (OR Sup. Ct., Oct. 8, 2015). En este caso, unos padres de Oregon miembros de un grupo religioso, «Followers 
of Christ Church», fueron condenados por homicidio involuntario en segundo grado tras la muerte de su hijo David nacido prematuramente y al que, gravemente enfermo, habían dejado morir sin atención médica a las pocas horas de nacer. Por sus creencias religiosas, lo habían ungido con aceite y rezado sobre él a fin de curarlo. El Tribunal Supremo de Oregon confirmó la sentencia recurrida sin aceptar la pretensión de estos padres que buscaban en su defensa la prueba del conocimiento que esa práctica, para ellos curativa, produciría la muerte de su hijo para poder ser considerados responsables de ella.

Koch v. Koch, 207 So. 3d 914 (FL App., Sept. 28, 2016). Aquí, un tribunal de apelación estatal confirmó la orden recurrida del tribunal inferior que, dentro del régimen de visitas acordado en un proceso de divorcio, había prohibido al padre tratar asuntos religiosos con sus tres hijos durante las dos horas de visita semanal que tenía. Los comentarios del padre, amenazas de castigo y demonización de la madre colocaban a los hijos en un estado de ansiedad y grave angustia emocional. De ahí que el bienestar y el interés superior de los menores aconsejaban esa prohibición.

Calgaro v. St Louis County, 2017 U.S. Dist. LEXIS 79551 (D. MN, May 23, 2017). En esta ocasión, una madre de un menor de 17 años que no vivía con ella y era independiente económicamente no pudo acceder al historial clínico y educativo de su hijo. El menor había comenzado a medicarse para un cambio de sexo sin consentimiento de la madre. El joven no había obtenido ninguna orden judicial de emancipación, pero un abogado sí le había facilitado una carta en la que se aseguraba estar emancipado legalmente. Y es que en el Estado de Minnesota la emancipación es un hecho del padre que debe ser apreciado según las circunstancias del caso, normalmente a juicio de un jurado. En este caso, el menor no podía ser considerado emancipado hasta que una orden judicial lo dispusiera, de ahí que la madre continuara con la custodia legal y física del menor. Sin embargo, ante la negativa a facilitarle los informes solicitados, la madre denunció esta situación creyendo que, sin proceso justo, se le había privado de ejercer sus derechos parentales en el cuidado de su hijo. El tribunal federal de distrito en esta sentencia falló a favor del condado y en contra de las pretensiones de la madre. Y es que aún suponiendo que los demandantes pudieron considerar emancipado al menor, esto no entrañaba el fin de los derechos parentales de la madre, algo que sólo podría suceder por orden judicial. 
Doe v. Christie, 136 S.Ct. 1155 (2016). El 29 de febrero de 2016 el Supremo negó el recurso de apelación que le había presentado «Liberty Counsel» el 10 de agosto de 2015 contra una decisión del tercer circuito favorable a la validez de una ley de New Jersey de 2013 (Bill A3371) por la que a los profesionales de salud no se les permitía asistir a menores de 18 años que desearan cambiar de orientación sexual («sexual orientation change efforts», SOCE ${ }^{24}$. Aunque la ley no imponía sanciones, sí que dejaba abierta la vía a expedientes disciplinares. Unos doctores cristianos y dos organizaciones denunciaron esa ley como violación de sus derechos constitucionales de libertad de expresión y religión. Como hiciera antes el noveno circuito con una ley similar de California ${ }^{25}$, el tercer circuito mantuvo ahora la ley de New Jersey, aunque con una notable diferencia. Por un lado, confirmó la sentencia recurrida y negó que el libre ejercicio de la religión hubiera sido violado. Pero por otro, sí entendió, a diferencia del tribunal de distrito y del fallo del noveno circuito, que había en juego aquí un tipo de discurso profesional (no conduct sino speech) protegido por la Primera Enmienda. Esa discrepancia de pareceres entre estos dos circuitos sobre la calificación de la actividad como expresión profesional provocó el recurso sin éxito ante la USSC (apelación rechazada el 4 de mayo de 2015 en King $v$. Christie, 135 S.Ct. 2048), volviendo a plantear de nuevo el recurso que una vez más fue rechazado en esta ocasión. Ya sabemos que la administración Obama, a través de la Casa Blanca, había pedido en el mes de abril del 2015 el fin de esta clase de terapias sobre jóvenes ${ }^{26}$. Por su parte, los demócratas introdujeron en el Congreso un proyecto de ley (Therapeutic Prevention Act,

${ }^{24}$ Cfr. Doe v. Governor of New Fersey, 783 F.3d 150 (3rd Cir., April 13, 2015).

${ }_{25}$ Una ley de California de 2012, SB 1172, también prohibió a profesionales de la salud mental, como psicólogos, psiquiatras, terapeutas u otros, ofrecer asistencia a menores de 18 años que quisieran cambiar o disminuir una conducta o atracción no deseada hacia personas del mismo sexo. Sabemos por la crónica anterior que esa polémica ley fue denunciada al entender que contravenía la libertad de expresión y los derechos de los menores a recibir el asesoramiento profesional que desearan. En un principio, un tribunal federal de distrito acogió esta tesis, pero el noveno circuito en apelación mantuvo la validez de la ley. Cuando el caso volvió a ese mismo circuito para reabrirlo en banc, el tribunal no quiso hacerlo con el voto en contra del juez O'Scannlain, al que se unieron dos jueces más, que pidió se revisara la ley bajo principios de free speech: Pickup v. Brown, 740 F.3d 1208, at 1215 (9th Cir., January 29, 2014) [O'Scannlain, J., dissenting]. La USSC negó la apelación presentada el 30 de junio de 2014 en Pickup v. Brown, 134 S.Ct. 2871 (2014), así como en el caso similar Welch v. Brown, 134 S.Ct. 2881 (2014).

${ }^{26}$ Cfr. https://petitions.whitehouse.gov/response/response-your-petition-conversion-therapy. 
HR 2450) al mes siguiente, instando a los Estados a su prohibición ${ }^{27}$. El Distrito de Columbia era el único que tenía una ley como las de California y New Jersey hasta el 20 de agosto de 2015, fecha en la que el gobernador de Illinois firmó la Youth Mental Health Protection Act, HB 217, aunque no entró en vigor hasta el 1 de enero de 2016. A estos Estados se sumaron ciudades como las de Cincinati en Ohio a primeros de diciembre de 2015, New York el 6 de febrero de 2016, Seattle el 3 de agosto de 2016, o la de Toledo en Ohio el 7 de febrero de 2017, aprobando incluso una prohibición aún más amplia para cubrir no sólo a los menores sino a toda persona. Mientras tanto, el 15 de febrero de este año 2017 un tribunal federal de distrito de Illinois, en Pastors Protecting Youth v. Madigan, 237 F. Supp. 3d 746 (ND IL 2017), afirmó que esa ley no era de aplicación al asesoramiento religioso o pastoral. Y el 1 de mayo de 2017, la USSC volvió a rechazar, en Welch v. Brown, 137 S.Ct. 2093 (2017), un nuevo recurso contra la ley SB 1172 de California, tras una sentencia del noveno circuito que no veía en ella violación alguna de las garantías constitucionales de libre ejercicio y/o de no establecimiento religioso ${ }^{28}$.

Advocate Health Care Network v. Stapleton, 137 S.Ct. 1652 (2017). Los días 12 y 15 de agosto de 2016 llegaron al Supremo diversos escritos solicitando la revisión de un par de casos a fin de esclarecer si la excepción contenida en la Employee Retirement Income and Security Act (ERISA) de 1974 sobre los planes eclesiales (church plan) de jubilación era o no de aplicación a aquellos planes que no eran establecidos por una iglesia en sentido estricto sino por organizaciones de salud afiliadas religiosamente a la iglesia. El caso tenía su importancia por hallarse en juego cerca de tres mil millones y medio de dólares y millones de trabajadores, 750.000 de ellos empleados en hospitales católicos. En ese primer momento, las controversias sobre las que se pedía al Supremo su intervención procedían del tercero y del séptimo circuito. El 29 de diciembre de 2015, el primero de los circuitos, en Kaplan v. St. Peter's Healthcare System, 810 F.3d 175 (3rd Cir. 2015), había respondido a la cuestión negativamente, de modo que esos planes, creados por ese siste-

\footnotetext{
${ }^{27}$ La Therapeutic Fraud Prevention Act, HR 2450, que enmendaría la Federal Trade Commission Act, fue introducida el 19 de mayo en la Cámara por los representantes demócratas de California Ted Lieu y de Washington Suzan DelBene. El 22 de mayo pasó al subcomité de la Cámara sobre comercio. Cfr. https://www.congress.gov/bill/114th-congress/house-bill/2450.

${ }^{28}$ Cfr. Welch v. Brown, 2016 U.S. App. LEXIS 17867 (9th Cir., October 3, 2016).
} 
ma particular de salud y no por la diócesis católica de Metuchen, New Jersey, no disfrutaban de la exención prevista en la ERISA. Pocos meses después, el séptimo circuito, haciendo una lectura literal de la normativa, llegaba a la misma conclusión en otro caso resuelto el 17 de marzo de 2016: Stapleton v. Advocate Health Care Network, 817 F.3d 517 (7th Cir. 2016). A estos dos casos se unió un tercero con idéntica respuesta, en esta ocasión en el noveno circuito: Rollins v. Dignity Health, 830 F.3d 900 (9th Cir., July 26, 2016). El 2 de diciembre de 2016 la USSC admitió los recursos de apelación presentados uniéndolos. La discusión tuvo lugar el 27 de marzo de 2017, llegando la sentencia el 5 de junio. La decisión, tomada por unanimidad de 8 jueces en un fallo en el que el recién incorporado Gorsuch no tomó parte, anuló las sentencias recurridas juzgando que los planes de jubilación de esos sistemas de salud propios de organizaciones religiosas afiliadas a las iglesias podían considerarse «planes eclesiales» a efectos de la exención prevista en la ERISA.

\section{Matrimonio}

V.L. v. E.L., 136 S.Ct. 1017 (2016). En esta opinión per curiam del 7 de marzo de ese año, la USSC anuló una decisión del Tribunal Supremo de Alabama que no había querido reconocer la jurisdicción de Georgia en un caso de adopción por una pareja de lesbianas que habían convivido entre 1995 y 2011. Una de ellas, E.L., concibió por inseminación artificial tres hijos mientras convivía con su pareja V.L. Las dos mujeres se desplazaron entonces a Georgia donde se le concedió a V.L. la adopción de esos hijos. Regresaron a Alabama y cuando se rompió esa relación se buscó la custodia compartida y un convenio regulador de visitas, sin que Alabama reconciera esa adopción. Como puede verse, los hechos ocurrieron antes de que la USSC sostuviera en Obergefell v. Hodges, 135 S.Ct. 2584 (June 26, 2015), decisión 5-4 a cargo del juez Kennedy, que las garantías de igual protección (equal protection) y de proceso justo (due process) de la Decimocuarta Enmienda consagraban en los Estados Unidos el derecho fundamental de las personas del mismo sexo a contraer matrimonio (same-sex marriage), respondiendo favorablemente a las dos cuestiones que se le plantearon: todo Estado debía conceder licencia para casarse a personas del mismo sexo y todo Estado debía reconocer esa clase de matrimonio legalmente celebrado en otro Estado. 
Pues bien, en relación a Obergefell, el 7 de abril de 2016 el primer circuito, en In re Conde-Vidal, 818 F.3d 765 (1st Cir. 2016), aplicó esta sentencia a Puerto Rico en contra del parecer de una decisión previa de un tribunal federal de distrito que no la había creido vinculante ${ }^{29}$. Pero es que esa sentencia del Supremo no supuso más que el origen de una serie de controversias que llegan hasta el presente. Algunas tan absurdas como la de aquel hombre que pretendió casarse con su ordenador portátil e interpuso una demanda contra el rechazo a concederle la correspondiente licencia para casarse en Kentucky, escrito en el que invocó a su favor la decisión del Supremo ${ }^{30}$. Aunque más importantes han sido aquellas en las que las personas del mismo sexo se han sentido discriminadas cuando no se les ha querido ofrecer ciertos servicios públicos relativos a la celebración de su matrimonio. Aquí los casos se han disparado con todo tipo de hipótesis: desde ceremonias en hoteles ${ }^{31}$, tartas de boda, reportajes fotográficos o videográficos del enlace ${ }^{32}$, diseños de tarjetas de invitación o de páginas web de bodas ${ }^{33}$, o adornos florales, sin olvidar algún

${ }^{29}$ Cfr. Vidal v. Garcia-Padilla, 2016 U.S. Dist. LEXIS 29651 (D.P.R., Mar. 8, 2016).

${ }^{30}$ Cfr. Sevier v. Davis, Case: 0:16-cv-00080-HRW (ED KY, filed, July 1, 2016), en https://es. scribd.com/document/317571575/Sevier-v-Davis.

31 Cfr. Wathen v. Walder Vacuflo, Inc., Charge No:2011SP2489 (IL HRC., March 22, 2016) y Wathen v. Walder Vocuflo, Inc., (IL HRC, Nov. 18, 2016). Una comisión estatal de derechos humanos falló en contra de un establecimiento Bed \& Breakfast que se opuso a celebrar en él un matrimonio entre personas del mismo sexo. La «broma» le salió al negocio por 30.000 dólares en gastos por angustia emocional, además de los 50.000 dólares que tuvo que pagar como honorarios de abogados: http://ftpcontent. worldnow.com/wand/order.pdf.

32 Cfr. Telescope Media Group v. Lindsey, 2017 U.S. Dist. LEXIS 153014 (D MN, September 20, 2017). Aquí una empresa de Minnesota que se encargaba de hacer reportajes videográficos de bodas denunció el 6 de diciembre de 2016 la ley de ese Estado que la obligaba a aceptar y participar en eventos contrarios a sus creencias religiosas. El tribunal, el 20 de septiembre de 2017, fallaba en contra de sus pretensiones, negando que su libre ejercicio se hubiera visto violado cuando la normativa denunciada (la «Minnesota Human Rights Act») era neutral y de general aplicación. Además dijo que la advertencia puesta en la website de la empresa alertando de su rechazo a ofrecer servicios a parejas del mismo sexo era algo contrario a la ley, sin poder reclamar en su defensa la garantía del free speech.

33 Cfr. Brush \& Nib Studio LC v. City of Phoenix, Case No. CV 2016-052251 (AZ Super. Ct., Sept. 19, 2016), en http://www.adfmedia.org/files/BrushNibPIdecision.pdf. El tribunal estatal negó aquí la orden pedida por el demandante que hubiera impedido la aplicación de la ordenanza municipal contraria a la discriminación por entender que no estaban en peligro sus derechos de libertad de expresión y de libre ejercicio. Por su parte, en 303 Creative, LLC v. Elenis, Case No. 1:16-cv-02372-MSK-CBS (D CO, Sept. 1, 2017), en http://www.adfmedia.org/files/303CreativeDecision.pdf, el diseñador de páginas web de bodas, que sólo trabajaba en caso de matrimonios heterosexuales, decidió interponer esta demanda contra un par de cláusulas de la ley estatal de Colorado. El tribunal no quiso pronunciarse sobre el fondo del asunto estando pendiente de decisión por la USSC un caso similar (Masterpiece Cake Shop). 
caso de venta de camisetas ${ }^{34}$, o inclusión en ferias de granjeros ${ }^{35}$, hasta de prestación de servicios funerarios ${ }^{36}$.

El 26 de junio de 2017, la USSC aceptaba entrar en un caso que le llegaba desde Colorado, una vez que su Tribunal Supremo había rechazado el recurso de apelación el 25 de abril. Se trataba del propietario de una pastelería que se había negado a ofrecer una tarta de boda a dos hombres para el día de su boda: Masterpiece Cake Shop v. Colorado Civil Rights Commission, 137 S.Ct. 2290 (2017). El tribunal estatal de apelación había fallado en contra del dueño de ese negocio, sin entender que sus derechos de libre ejercicio religioso y de libertad de expresión hubieran sido conculcados cuando la Comisión estatal de derechos civiles le sancionó por violar la legislación de establecimientos públicos ${ }^{37}$. El

${ }^{34}$ Cfr. Lexington Fayette Urban County Human Rights Commission v. Hands On Originals, Inc., 2017 Ky. App. Unpub. LEXIS 371 (KY Ct. App., May 12, 2017). En este caso, un tribunal estatal de Kentucky sí falló a favor del derecho de un negocio a no imprimir camisetas LGBT.

35 Cfr. Country Mill Farms, LLC v. City of East Lansing, Case No. 1:17-cv-00487 (WD MI, filed 5/31/2017), en http://www.adfmedia.org/files/CountryMillFarmsComplaint.pdf. A Stephen Tennes, dueño de una granja, se le negó participar en la feria anual de granjeros («East Lansing Farmer's Market») por las declaraciones contrarias al same-sex marriage que había hecho en «Facebook». Como católico que era, dijo que podían celebrarse matrimonios en su granja pero sólo entre un hombre y una mujer. La ciudad intentó presionarle para que no asistiera a la feria y finalmente cambió la ordenanza municipal para evitar su presencia. El tribunal federal de distrito acaba de darle la razón al granjero al ordenar el 15 de septiembre a la ciudad que le permita participar en la feria para poder vender sus productos: Country Mill Farms, LLC v. City of East Lansing, No. 1:17-cv-487 (WD MI, September 15, 2017), cfr. http://www.adfmedia.org/files/ CountryMillFarmsPI.pdf.

${ }^{36}$ Cfr. Zawadski v. Brewer Funeral Services, Inc., Case No. 55CI1:17-cv-00019-CM (MS Cir. Ct., filed March 7, 2017), en http://www.lambdalegal.org/sites/default/files/legal-docs/downloads/ 012_2017-03-07_first_amended_complaint.pdf. En este caso, la funeraria retiró el acuerdo de servicios fúnebres, traslado del difunto y cremación, al enterarse que se trataba de un hombre casado con otro. En juego estaba la ley estatal de Mississippi (Protecting Freedom of Conscience from Government Discrimination Act, HB 1523) cuya constitucionalidad fue impugnada sin éxito en el quinto circuito: Barber v. Bryant, 860 F.3d 345 (5th Cir., June 22, 2017).

37 Cfr. Craig v. Masterpiece Cake Shop, Ltd., 370 P.3d 272 (Colo. App., August 13, 2015). Pues bien, recurrida esta sentencia al Supremo y una vez admitida la apelación, este Tribunal recibió del Departamento de Justicia el 7 de septiembre de 2017 un escrito, amicus brief, en defensa de la libertad de expresión del dueño de la pastelería: http://www.scotusblog.com/wp-content/uploads/ 2017/09/16-111-tsac-USA.pdf. En el mismo sentido se presentó ese día otros dos escritos en apoyo de las posiciones del demandante, uno de la Conferencia de obispos católicos (USCCB), en http://www.scotusblog.com/wp-content/uploads/2017/09/16-111-tsac-USCCB-et-al.pdf y otro de la «Becket Fund for Religious Liberty», en http://www.scotusblog.com/wp-content/ uploads/2017/09/16-111-tsac_the_becket_fund.pdf. El New York Times del 16 de septiembre de 2017 aventuraba la solución de manos del Juez Kennedy, firme defensor de la libertad de expresión pero también de los derechos civiles de los gays, en un tribunal eventualmente dividido: A. LiPTAK, Cake Is His 'Art'. Co Can He Deny One to a Gay Couple?, September 16, 2017, en «New York Times», en https://www.nytimes.com/2017/09/16/us/supreme-court-baker-same-sex- 
caso es que otra controversia similar, en este caso no con pasteles de boda sino con flores, se le presentó también a la USSC solicitando al Tribunal que uniera los dos casos para ofrecer una misma solución o, al menos, suspendiera su ejecución hasta resolviera el aceptado. Aquí, en Arlene's Flowers, Inc. v. State of Washington (cert. filed, July 14, 2017), fue la floristería la que se negó, por razones religiosas, a vender flores para una boda entre personas del mismo sexo. El Tribunal Supremo de Washington también dijo aquí que esa decisión suponía un trato discriminatorio contrario a la ley ${ }^{38}$. Habrá que esperar al próximo año judicial para poder ver la respuesta de la USSC. También se le ha pedido que se pronuncie, en Neely v. Wyoming Commission on Fudicial Conduct and Ethics (cert. Filed, August 4, 2017), sobre el caso del juez de Wyoming que, por razones religiosas, rechazaba la celebración de matrimonios del mismo sexo y que el Tribunal Supremo de ese Estado juzgó que contravenía su código de conducta judicial ${ }^{39}$.

Dumont v. Lyon, $\mathrm{n}^{\circ}$ 2:17-cv-13080-PDB-EAS (ED MI, filed September 20, 2017). Michigan aprobó unas leyes en el 2015 (House Bills 4188, 4189 y 4190) por las que agencias de servicios sociales, religiosamente afiliadas, pudieran operar como centros de acogida y adopción. En este caso, dos matrimonios de personas del mismo sexo y un contribuyente del Estado, con la asistencia legal de la ACLU, denunciaron el empleo de criterios religiosos que las agencias hacían en sus decisiones, descartando por su orientación sexual a familias cualificadas, algo que, a su juicio, violaba las cláusulas de no establecimiento y de igual protección. Aun es pronto para predecir el recorrido del caso.

Brown v. Buhman, 137 S.Ct. 828 (2017). El 23 de enero de este año la USSC rechazó el recurso presentado por la familia polígama protagonista del

marriage. html hp \&action $=$ click \&pgtype $=$ Homepage $\&$ clickSource $=$ story - heading $\&$ module=first-column-region\&region=top-news\&WT.nav=top-news. Pero ¿y si la situación fuera la contraria? ¿Y si una pastelería fuera la que se opusiera a la venta de una tarta con un mensaje cristiano contrario al same-sex marriage y le fuera negada? Pues en este caso, un juez de Florida dijo que eso no era discriminación religiosa: Mannarino v. Cut the Cake Bakery, Case No. 16-3465 (FL Div. Admin. Hearings, Feb. 9, 2017), en https://www.doah.state.fl.us/ROS/2016/ 16003465.pdf.

${ }^{38}$ Cfr. State v. Arlene's Flowers, Inc., 2017 Wash. LEXIS 222 (Wash., Feb. 21, 2017); State v. Arlene's Flowers, Inc., 2017 Wash. LEXIS 216 (Wash., Feb. 16, 2017).

39 Cfr. Neely v. Wyoming Commission on Fudicial Conduct and Ethics, 390 P.3d 728 (WY Sup. Ct., March 7, 2017). 
show televisivo «Sister Wives» contra la legislación de Utah que prohíbe la poligamia. El décimo circuito había respaldado la ley estatal ${ }^{40}$.

Pavan v. Smith, 137 S.Ct. 2075 (2017). El pasado 26 de junio la USSC, al aceptar el recurso que se le planteó, anuló una decisión del Tribunal Supremo de Arkansas a fin de ofrecer a los esposos del mismo sexo igual tratamiento legal que los heterosexuales, reenviando el caso al tribunal inferior para proceder según los principios asentados en Obergefell. El caso tenía que ver con certificados de nacimiento y es que, según la ley de Arkansas, sólo el esposo, no la esposa, de la mujer que daba a luz figuraba en ese certificado ${ }^{41}$. El juez Gorsuch dejó constancia de su desacuerdo con la decisión de la USSC y esa lógica expansiva de Obergefell en una opinión disidente a la que se le unieron los jueces Thomas y Alito ${ }^{42}$.

McQueen v. Gadberry, 507 S.W.3d 127 (MO App., November 15, 2016). En este caso, un tribunal estatal de Missouri, en un poceso de divorcio, sostuvo que los embriones congelados por fecundación in vitro, a partir del esperma del esposo y de los óvulos de la mujer, eran propiedad del matrimonio, es decir, «cosas» que no debían ser tratados como «personas». La esposa deseaba que fuera así para que se le concediera la custodia sobre ellos a fin de poder implantárselos en orden a un posible embarazo futuro y no tener que contar necesariamente con la autorización del esposo, como propiedad común que era. En cambio, el tribunal estatal pensó que esa pretensión de la mujer podría vulnerar los derechos del esposo (su privacidad y su derecho a no procrear).

\section{EDUCACIÓN}

Gloucester County School Board v. G.G., 137 S.Ct. 1239 (2017). El 6 de marzo de 2017, la USSC reenvió al cuarto circuito, anulando la decisión recurrida, un caso de acceso a los baños y vestuarios en la escuela por alumnos con una identidad de género distinta a la biológica, es decir, un transgénero. El Supremo había admitido la apelación el 28 de octubre de 2016 y probablemente se hubiera pronunciado sobre el fondo del asunto si el 22 de febre-

${ }^{40}$ Cfr. Brown v. Buchanan, 822 F.3d 1151 (10th Cir., May 13, 2016).

${ }^{41}$ Cfr. Smith v. Pavan, 2016 Ark. 437 (Ark., Dec. 8, 2016).

42 Cfr. Pavan v. Smith, 137 S.Ct. 2075, at 2079 [Gorsuch, J., dissenting] (2017). 
ro de 2017 los Departamentos de Justicia y Educación, en la recién estrenada administración Trump, no hubieran acordado revocar la política anterior de Obama cuya aplicación, por otra parte, había quedado paralizada por una orden de un tribunal federal de distrito de Texas en agosto de $2016^{43}$. Pues bien, la interpretación que hacía la administración Obama del Título IX de las Education Amendments de 1972, coherente con su acción en otras áreas como las relaciones laborales, el campo de la salud o del ejército ${ }^{44}$, exigía en este caso que los alumnos, para evitar cualquier discriminación por razón de sexo, pudieran acceder a esos baños y vestuarios escolares según su identidad de género, una cuestión que suscitó una extraordinaria polémica durante esos años desde que quedara abiertamente manifiesta la postura de la administración en una carta del departamento de educación fechada el 7 de enero de $2015^{45}$. El caso es que esas directrices, con el cambio habido en la Casa Blanca, fueron anuladas por las nuevas ${ }^{46}$ provocando un cambio en las circunstancias del caso sobre el que debía pronunciarse la USSC, razón por la que decidió anular la sentencia recurrida y reenviar el caso al tribunal de apelación para que resolviera según esa nueva política de la administración con instrucciones muy precisas desde el mes de junio de 2017 a fin de evitar hostilidad en la escuela hacia esos alumnos ${ }^{47}$. El cuarto circuito se pronunció el 2 de agosto de este año

${ }^{43}$ Cfr. Texas v. United States, 201 F. Supp. 3d 810, at 836 [O'Connor, J.] (N.D. Tex., Aug. 21, 2016).

${ }^{44}$ No obstante el número de denuncias planteadas, la agenda de la administración Obama en materia de igualdad de derechos para las personas transgénero siguió adelante en campos diversos: en el Ejército permitiendo, como más adelante veremos, el Secretario de Defensa Ash Carter, el 30 de junio de 2016, el servicio y atención a esas personas; en todos los edificios federales autorizando el acceso a los baños públicos según la identidad de género por una directiva en agosto de 2016 de la «General Services Administration», GSA; o en el área de salud según una normativa del HHS de mayo de ese mismo año. Estas acciones fueron provocando una gran tensión multiplicándose las denuncias.

45 Puede consultarse esta carta de James A. Ferg-Cadima enviada desde la oficina de derechos civiles del Departamento de Educación en respuesta a una previa de Emily T. Prince, en http:// www.bricker.com/documents/misc/transgender_student_restroom_access_1-2015.pdf.

46 Puede verse la declaración conjunta de los dos Departamentos de Justicia y Educación firmada el 22 de febrero, en https://www.justice.gov/opa/press-release/file/941551/download. El Presidente Trump se unió a las tesis del nuevo fiscal general Jeff Sessions, parece más partidario a la revocación de esas directrices de Obama que la nueva secretaria del Departamento de Educación Betsy DeVos, a juzgar por las declaraciones que hicieron ambos, cfr. J. W. PETERS - J. BECKER - J. HiRschfeld Davis, Trump Rescinds Rules on Bathrooms for Transgender Students, NY Times, Feb. 22, 2017, en https://www.nytimes.com/2017/02/22/us/politics/devos-sessions-transgender-students-rights.html?_r=0.

47 Es lo que hizo el 6 de junio la Oficina de derechos civiles del Departamento de Educación, con la intervención directa de su Secretaria Betsy DeVoss, preocupada de la posible discriminación, acoso o bullying a los estudiantes transgénero, incluyendo el uso de nombres o pronombres para 
en Grimm v. Gloucester County School Board, 2017 U.S. App. LEXIS 14158 (4th Cir. 2017). Aquí este tribunal de apelación resolvió reenviar también el caso al tribunal federal de distrito de Virginia para ver si se podía cerrar, tras el cambio de dirección. En este litigio recordemos que una junta escolar de un condado de ese Estado había exigido que los alumnos usaran los baños que correspondieran a su sexo biológico, no a su identidad de género, corrigiendo así ciertas adaptaciones que había autorizado uno de sus institutos. Esa medida fue denunciada por Gavin Grimm, el alumno transgénero al que, nacido niña, se le había permitido el acceso al baño de los chicos de su bigh school, como discriminación contraria a la igualdad exigida por el Título IX de la ley federal de educación así como por la garantía constitucional de igual protección. El cuarto circuito le dio la razón el 19 de abril de 2016 en G.C. v. Gloucester County School Board, 822 F.3d 709 (4th Cir. 2016), siguiendo la interpretación que ofreciera el 7 de enero de 2015 la oficina de derechos civiles del Departamento de Educación, según la cual cuando una escuela decidiera separar sus estudiantes por razón de sexo, como sería el caso del acceso a los baños, los alumnos transgénero deberían ser tratados según su identidad de género. Pues bien, al mes siguiente de la sentencia del cuarto circuito, el 13 de mayo de 2016, los Departamentos de Justicia y Educación ofrecieron una guía a seguir por escuelas y universidades a fin de garantizar los derechos civiles de los estudiantes transgénero en la misma dirección ${ }^{48}$. La reacción no se hizo esperar y el 25 de mayo once Estados (Alabama, Arizona, Georgia, Louisiana, Maine, Oklahoma, Tennessee, Texas, Utah, West Virginia, Wisconsin) demandaron a la administración Obama por la interpretación que hacía del Título IX de la ley de enseñanza y del Título VII de la Rights Civil Act de 1964 en materia de trabajo en State of Texas v. United States, Case 7:16-cv00054-O (Filed May 25, 2016) ${ }^{49}$. Pero, volviendo ahora al caso de Virginia, el

referirse a esa clase de estudiantes que no coincidan con su nuevo género: http://files.eqcf.org/ wp-content/uploads/2017/06/2017.06.06_OCR-Instructions-to-the-Field-Re-TransgenderStudents.pdf. Esto provocó el descontento de algunos grupos cristianos como «Liberty Counsel» que vieron en estas instrucciones un paso atrás en la línea emprendida por la nueva administración.

${ }^{48}$ Cfr. https://www2.ed.gov/about/offices/list/ocr/letters/colleague-201605-title-ix-transgender. pdf.

49 Cfr. https://www.texasattorneygeneral.gov/files/epress/files/2016/complaint_FM.pdf. Es cierto que, con el tiempo, a esos Estados se fueron añadiendo 13 más en diversas acciones: los de Mississippi y Kentucky en Texas v. United States, 201 F. Supp. 3d 810 (N.D. Tex., Aug. 21, 2016) y Texas v. United States, 2017 U.S. App. LEXIS 2373 (5th Cir. Tex., Feb. 9, 2017); un distrito escolar de Ohio en Board of Education of the Highland Local School District v. United States Dep't of 
departamento escolar no se conformó y quiso reabrir el caso en banc, algo que volvió a ser rechazado el 31 de mayo, razón por la que se pidió intervenir a la USSC.

Whitaker v. Kenosha Unified School District, 858 F.3d 1034 (7th Cir., May $30,2017)$. Antes de que se pronunciara en agosto el cuarto circuito sobre la cuestión del acceso a los baños por los estudiantes transgénero, tras el reenvío del caso por la USSC en Gloucester, el séptimo circuito en un caso similar dijo a finales de mayo que a un alumno de Wisconsin de 17 años, y con una identidad de género distinta a la de su nacimiento, se le debía permitir el acceso a los baños de los chicos, pues lo contrario supondría un daño irreparable en el proceso de transición del alumno y para su bienestar emocional. El tribunal no tuvo en cuenta el derecho de privacidad o intimidad de los otros alumnos, llegando a afirmar tal cual que la presencia del transgénero no entraña más riesgo para sus compañeros que la de un chico del mismo sexo demasiado curioso que quisiera echar un vistazo a sus colegas. $\mathrm{Y}$ precisamente éste es el argumento en el que se basó la demanda interpuesta por un alumno de una bigh school de Pennsylvania denunciando la política escolar al permitir a estudiantes transgénero la entrada a su baño y vestuario. En Doe v. Boyertown Area School District, Case No. 17-1249 (ED PA, filed, March 21, 2017), el demandante, Joel Doe, nos habla de vergüenza, de violación de privacidad, de intimidad, de humillación, degradación, o pérdida de dignidad, cuando se encontró compartiendo vestuario con un individuo parcialmente desnudo que era anatómicamente una mujer ${ }^{50}$. Pues bien, el 25 de agosto el tribunal federal de distrito, cuando se habían sumado a la posición demandante otros tres menores, en Doe v. Boyertown Area School District, 2017 U.S. Dist. LEXIS 137317 (ED PA, August 25, 2017), negó la orden solicitada por ellos a fin de evitar esa política escolar por más tiempo. El tribunal no creyó que su daño fuera irreparable y no apreció un derecho constitucional de privacidad tan amplio como pretendían.

Educ., 2016 U.S. Dist. LEXIS 107614 (S.D. Ohio, Aug. 15, 2016), Board of Education of the Highland Local School District v. U.S. Dep't of Educ., 208 F. Supp. 3d 850 (S.D. Ohio, Sept. 26, 2016) y Dodds v. United States Dep't of Educ., 845 F.3d 217 (6th Cir., Dec. 15, 2016); o los Estados de Arkansas, Kansas, Michigan, Montana, Nebraska, North Dakota, Ohio, South Carolina, South Dakota y Wyoming en State of Nebraska v. United States, Case 4:16-cv-03117-JMG-CRZ (D. NE., filed, July 8, 2016).

${ }^{50}$ Cfr. http://www.adfmedia.org/files/DoeBoyertownComplaint.pdf, p. 7, nn. 30-31. 
Payne v. University of Southern Mississippi, 137 S.Ct. 475 (2016). El 14 de noviembre de 2016 la USSC no admitió el recurso presentado ante una decisión del quinto circuito que mantuvo el fallo recurrido de un tribunal federal de distrito de Mississippi para el que la garantías constitucionales de la Primera Enmienda (free speech y free exercise) no impedían la sanción disciplinaria impuesta a un profesor de una universidad pública por sus expresiones religiosas, cristianas, en el ejercicio de sus deberes como profesor $^{51}$. Y ese mismo día, en COPE v. Kansas State Bd. of Educ., 137 S.Ct. 475 (2016), la USSC tampoco quiso entrar en otro caso en el que el décimo circuito había fallado a favor del currículo escolar de ciencias en secundaria sin ver en él nada contrario a la garantía constitucional de no establecimiento, no obstante las objeciones poco convincentes, a juicio del tribunal, del demandante de querer promover con ello una cosmovisión no religiosa ${ }^{52}$.

Kennedy v. Bremerton School District, 2017 U.S. App. LEXIS 16106 (9th Cir., 2017). El 23 de agosto de este año, el noveno circuito negó la petición presentada por un entrenador de futbol americano de una bigh shool de Washington que, desafiando la política del distrito escolar, se arrodillaba y rezaba tras los partidos en la línea de las 50 yardas del campo. Este tribunal de apelación confirmó la decisión recurrida y dijo que el entrenador, como funcionario público que era, no podía expresarse en ese momento de un modo contrario al requerido por la escuela.

Trinity Lutheran Church of Columbia, Inc. v. Comer, 137 S.Ct. 2012 (2017). El 26 de junio de 2017, tras la discusión del caso el 19 de abril, la USSC en una sentencia 7 a 2 falló a favor de la iglesia luterana demandante a la que el Estado de Missouri, a través de su departamento de recursos naturales, le había negado la ayuda pedida, dentro de un programa secular de subvenciones, para revestir el patio de recreo de su guardería y escuela infantil con material extraido de neumáticos desechables. El Estado sostenía que la «Enmienda Blaine» de su Constitución (Artículo I, Sección 7 por la que no pueden destinarse fondos públicos a la «ayuda de alguna iglesia, sección o denominación religiosa») no permitía esa clase de asistencia financiera directa cuando la beneficiaria fuera una iglesia. Y el octavo circuito le había dado la razón sin ver

${ }^{51}$ Cfr. Payne v. University of Southern Mississippi, 643 Fed.Appx. 409 (5th Cir., April 12, 2016).

${ }^{52}$ Cfr. COPE v. Kansas State Bd. of Educ., 821 F.3d 1215 (10th Cir., April 19, 2016). 
en la citada Enmienda, ni en la decisión tomada, nada contrario a las garantías constitucionales de libre ejercicio religioso, no establecimiento de la religión o de igual protección de la Primera y Decimocuarta Enmiendas ${ }^{53}$. La opinión mayoritaria del Tribunal fue redactada por su presidente, el Chief Justice Roberts, al que se unieron plenamente los jueces Kennedy, Alito y Kagan. También lo hicieron los jueces Thomas y el recién incoporado Gorsuch, salvo en una nota a pie de página de la opinión mayoritaria que parecía limitar el resultado al caso presente. Por eso ofrecieron cada uno su propia opinión, uniéndose recíprocamente el uno al otro, concurriendo en parte y defendiendo el libre ejercicio religioso de la parte demandante. Pues bien, para la mayoría, la política del departamento estatal suponía una discriminación clara que sólo obedecía al carácter religioso del destinatario de la ayuda. La iglesia, miembro de la comunidad, no pedía directamente ninguna ayuda para sí sino sólo participar en un programa secular de subvenciones sin verse excluida del mismo por su carácter religioso. Esa decisión del gobierno exigía la aplicación del más estricto escrutinio que no superaba. No lo vieron así las jueces Sotomayor y Ginsburg. La primera dejó constancia de su oposición en una larga opinión disidente de 27 páginas a la que se unió la juez Ginsburg. Para ella, la USSC se apartaba de todo precedente e historia en las relaciones entre Iglesia y Estado, invalidando las medidas constitucionales de 39 Estados y reconociendo por primera vez que el gobierno sí podía destinar fondos públicos a las iglesias. Al día siguiente del fallo del Supremo, este mismo Tribunal reenvió cuatro casos de ayuda escolar pendientes de revisión a los tribunales inferiores para que procedieran según lo dispuesto en Trinity Lutheran Church: cuatro de esos casos venían de Colorado y uno de New $\mathrm{Mexico}^{54}$. Y una de las primeras aplicaciones federales de la sentencia del Supremo tuvo lugar el 25 de julio cuando un tribunal de Michigan, en Council of Organizations and Others for

53 Cfr. Trinity Lutheran Church of Columbia, Inc. v. Pauley, 788 F.3d 779 (8th Cir. Mo., May 29, 2015).

${ }^{54}$ Cfr. Colorado State Board of Education v. Taxpayers for Public Education, 137 S.Ct. 2325 (June 27, 2017); Doyle v. Taxpayers for Public Education, 137 S.Ct. 2324 (June 28, 2017); y Douglas City School District v. Taxpayers for Public Education, 137 S.Ct. 2327 (June 27, 2017). En estos tres casos el Tribunal Supremo de Colorado había anulado un programa de bono o becas escolares en el condado de Douglas: Taxpayers for Pub. Educ. v. Douglas County Sch. Dist., Taxpayers for Pub. Educ. v. Douglas County Sch. Dist., Taxpayers for Pub. Educ. v. Douglas County Sch. Dist., 351 P.3d 461 (Colo., June 29, 2015), 351 P.3d 461 (June 29, 2015). En New Mexico Association of Nonpublic Schools v. Moses, 137 S.Ct. 2325 (June 27, 2017), el Tribunal Supremo de New Mexico había anulado un programa estatal de préstamo de libros de naturaleza secular, no religiosa, a estudiantes de escuelas privadas y parroquiales: Weinbaum v. Skandera, 367 P.3d 838 (N.M., Dec. 17, 2015). 
Education About Parochiaid v. State of Michigan, Case No. 17-000068-MB (MI Ct. Cl., July 25, 2017), sostuvo que la decisión no se podía aplicar a la prohibición neutral de financiación de escuelas privadas. En este caso, el legislador estatal había asignado una partida de dos millones y medio de dólares para que las escuelas privadas pudieran cumplir con las exigencias estatales y fue entonces cuando una orden judicial paralizó esta decisión. Ahora este tribunal federal no veía ninguna razón para levantar esa orden a pesar de la sentencia reciente de la USSC, pues la medida prevista en el Artículo 8, sección 2 de la Constitución estatal, era de neutral y general aplicación, sin expresa discriminación ${ }^{55}$. Y el 6 de octubre de 2017, el Supremo de Vermont tuvo en cuenta esta decisión de la USSC, Trinity Church Lutheran (2017), en un caso de subvención municipal destinada a la rehabilitación de un edificio histórico que era una iglesia (la «United Church of Cabot»): Taylor v. Town of Cabot, 2017 VT 92, 2017 Vt. LEXIS 114 (VT, Oct. 6. 2017).

CBM Ministries of South Central Pennsylvania v. Richards, 2017 U.S. Dist. LEXIS 151305 (MD PA, September 19, 2017). En este caso, el tribunal federal sostuvo la regulación estatal de Pennsylvania sobre inspección de autobuses de la escuela empleados para el traslado de alumnos de centros públicos en programas escolares de tiempo libre (release time programs). Estos programas de un máximo de 36 horas al año permitían asistir a los estudiantes que así lo desearan, con la autorización de sus padres y durante el día escolar, a clases de biblia que eran impartidas en iglesias y centros comunitarios cercanos a la escuela. Este tribunal mantuvo ahora la normativa como neutral y de general aplicación sin violar la garantía de libre ejercicio invocada por la organización cristiana no lucrativa que denunció la normativa.

\section{RLUIPA: PRESOS Y URBANISMO}

La RLUIPA del 2000, 114 Stat. 803, 42 U.S.C. $\$ 2000$ cc et seq., fue aprobada tras ser anulada la aplicación estatal de la RFRA de 1993 en City of Boerne (1997). El fin era ofrecer mayor protección federal y estatal al libre ejercicio de la religión en dos áreas de especial necesidad: regulación urbana (sección 2) y normativa penitenciaria o de otras instituciones que tuvieran in-

${ }_{55}$ Cfr. http://www.aclumich.org/sites/default/files/2017-07-25_Opinion_Prelim_Injunction.pdf. 
ternos (sección 3). En estos casos se debía operar un equilibrio de intereses (balancing test o Sherbert test, seguido en Sherbert 1963 y Yoder 1972 pero no en Smith 1990): para que un ejercicio religioso pudiera ser limitado sustancialmente (substantial burden), el gobierno -federal, estatal, o local- debería demostrar que lo exigía así un poderoso interés público (compelling state interest), siendo ésta la medida menos restrictiva posible (least restrictive means).

Andon v. City of New Port News, 813 F.3d 510 (4th Cir., February 9, 2016). El cuarto circuito falló a favor de la junta de urbanismo de una ciudad de Virginia que había rechazado la petición de modificar el uso del suelo para permitir una Iglesia en él. Al confirmar la decisión recurrida, el tribunal de apelación no juzgó que el libre ejercicio de la religión garantizado por la RLUIPA se hubiera visto afectado cuando la negativa municipal no suponía una carga sustancial si los demandantes no tuvieron una expectativa razonable de uso religioso como Iglesia de esa propiedad, más bien lo contrario, al ser advertidos, cuando presentaron la petición de cambio, que la solicitud no sería concedida por no cumplir uno de los requisitos legales, de ahí que asumieran ya entonces un posible resultado desfavorable.

Livingston Christian Schools v. Genoa Charter Twonship, 858 F.3d 996 (6th Cir., June 2, 2017). Una escuela cristiana decidió cambiar de lugar y situarse en el terreno de una iglesia en otra ciudad de Michigan con la que firmó un contrato de arrendamiento. Fue entonces cuando la ciudad notificó a la escuela arrendataria que debía contar con una licencia de uso especial antes de empezar a operar como escuela. La iglesia arrendataria solicitó entonces de la junta de urbanismo la oportuna licencia que le fue denegada y la escuela lo denunció como contrario a la garantía de libre ejercicio religioso bajo la RLUIPA. El tribunal federal de distrito le dio la razón a la ciudad y el sexto circuito confirmó esa decisión recurrida al negar que la ciudad hubiera impuesto una carga sustancial sobre el libre ejercicio de la escuela por no haber probado que el lugar en el que se encontraba la escuela antes fuera inadecuado o que no hubiera otra posible alternativa en la nueva ciudad. Es más, si la negativa municipal le ocasionó a la escuela retrasos, gastos e incertidumbres fue en gran medida por causa suya al haber arrendado su propiedad una vez iniciado el litigio.

Tree of Life Christian Schchols v. City of Upper Arlington, 823 F.3d 365 (6th Cir., May 18, 2016). El sexto circuito, corrigiendo el fallo recurrido, dijo que 
una ciudad de Ohio podía haber discriminado, en contra de la cláusula legal de «equal terms» de la RLUIPA, a una escuela religiosa cuando le había negado la licencia pedida para cambiar el uso del suelo en una zona comercial. La ciudad justificó su negativa por el interés municipal de maximizar sus ingresos fiscales, sin embargo la ley urbana sí permitía a otras entidades no religiosas sin ánimo de lucro como hospitales o centros de atención ambulatoria, en similares circunstancias, establecerse en esa zona. Por eso el tribunal de apelación reenvió el caso al inferior para resolver si había habido o no discriminación.

Affordable Recovery Housing v. City of Blue Island, 860 F.3d 580 (7th Cir. June 21, 2017). Una organización, dedicada a la atención, residencia y recuperación de hombres adultos con problemas de drogadicción y alcoholismo, convenció a unas monjas católicas en una ciudad al sur de Chicago para que les dejaran alojarse en sus propiedades a cambio de una renta. La ciudad exigió que, para ocupar los edificios, debían instalar en las habitaciones aspersores contra incendios, la organización no lo hizo y los residentes se vieron forzados a abandonar el lugar. Entonces fue cuando la demandante denunció sin éxito que esa medida había violado su libre ejercicio religioso, tanto bajo la Illinois RFRA como bajo la RLUIPA, pues la expulsión de los residentes había obedecido en su momento a una preocupación sobre su seguridad y, en relación a la RLUIPA, no se exigió finalmente el requisito contra incendios en las habitaciones (una regla de urbanismo cuyo cumplimiento podría condicionar el uso del edificio) tras la obtención del permiso del establecimiento como casa de rehabilitación con una altura menor de cuatro pisos.

Harbor Missionary Church v. City of San Buenaventura, 642 Fed. Appx. 726 (9th Cir., March 14, 2016). El noveno circuito anuló el fallo recurrido y determinó que el libre ejercicio religioso de esta iglesia, ocupada en el cuidado y atención de los sin techo como parte integral de su religión, había sido sustancialmente limitado al negarles la ciudad la licencia solicitada por los gastos ocasionados, la incertidumbre creada y el retraso sustancial. Además, para este tribunal, el interés de la ciudad en la prevención del crimen y en garantizar la seguridad podría ser importante, pero éste no justificaba que el tribunal de distrito hubiera concluido sin más análisis que la denegación de la licencia fuera la medida menos restrictiva para lograr ese poderoso interés. 
Mesquite Grove Chapel v. DeBonis, 633 Fed. Appx. 906 (9th Cir., Dec. 18, 2015). El noveno circuito confirmó la decisión recurrida en un caso en el que a una mezquita el inspector y la junta de urbanismo le había negado la licencia solicitada por no entrar dentro de la definición urbana de iglesia. El Tribunal de apelación negó que la carga impuesta sobre la mezquita, el cambio de lugar o la necesidad de presentar una solicitud modificada, fueran sustanciales, cuando no había prueba que otra zona fuera inadecuada.

Martin v. Houston, 196 F. Supp. 3d 1258 (M.D. Ala., June 25, 2016). Un pastor cristiano ocupado en la rehabilitación de delincuentes sexuales varones consideraba su misión religiosa recibir a esas personas en una parcela de su propiedad adyacente a su iglesia e imponerles unas reglas de convivencia a fin de facilitar su recuperación y reinserción. El legislador de Alabama (Chilton County Anti-Clustering Law, HB 556) en 2014 decidió intervenir prohibiendo, en el condado de Childton, que esa clase de convictos ni residieran en la misma casa ni lo hicieran a menos de 90 metros (300 pies). Esto hacía imposible la misión del pastor. La medida fue denunciada como un acto contrario a su libre ejercicio religioso bajo la RLUIPA y un tribunal federal de distrito entendió que la normativa entraba dentro de la esfera de la ley federal del 2000 (como zoning law que era) y que se había producido en el caso una limitación sustancial de su libre ejercicio al forzarle a dejar su ministerio. La ley fue derogada finalmente el 30 de agosto de 2016.

Milosavlejevic v. City of Brier, 2017 U.S. Dist. LEXIS 145012 (WD Wash., Sept. 7, 2017). En este caso, un tribunal federal de Washington dijo que una ciudad de este Estado no había violado la RLUIPA cuando negó al demandante el permiso para construir en su propiedad una capilla ortodoxa con dos cúpulas de casi catorce metros. El tribunal dijo que el libre ejercicio del demandante no había sido lesionado de forma sustancial cuando tenía a su disposición lugares alternativos de oración y la ciudad no le impedía rezar en ellos o en su casa.

Immanuel Baptist Church v. City of Chicago, 2017 U.S. Dist. LEXIS 154965 (ND Ill., September 22, 2017). Una iglesia baptista de Chicago que no había podido comprar un edificio para sus servicios, denunció la validez de la ordenanza municipal sobre aparcamiento que se le aplicaba. La iglesia pedía ser tratada como una biblioteca y la ciudad se lo negó. Para el tribunal esa 
diferencia de trato respondía a la situación distinta de una y otra, sin que se viera afectada la cláusula de «equal terms» de la RLUIPA, aunque sí dejaba abierta la puerta para que la demandante retomara el argumento de esta reclamación, una vez corregida.

In the Matter of the Application of Bonnie Septimus v Board of Zoning Appeals for the Incorporated Village of Lawrence, 22 N.Y.S.3d 815 (NY Sup. Ct., Dec. 16, 2015). En este caso una sinagoga que quería ampliar sus servicios se encontró con la negativa del vecindario por los problemas de tráfico que ello podría suponer. Cuando la sinagoga quiso ampliar su edificio, el departamento local de urbanismo levantó las restricciones que había puesto anteriormente al uso diario bajo una serie de condiciones: se lo concedió por el periodo de un año, reevaluable al año siguiente. El tribunal encontró esta decisión del ente local como la medida menos restrictiva para alcanzar el poderoso interés gubernamental en mantener el orden de la zona residencial. De ahí que el Supremo de New York rechazara la petición de Septimus contra la decisión local.

Bruce v. Samuels, 136 S.Ct. 627 (2016). El 12 de enero de 2016 la USSC resolvió por unanimidad una controversia que tuvo que ver con una de las secciones de la Prison Litigation Reform Act (PLRA), 28 U.S.C. $\$ 1915$. La ley fue aprobada por el Congreso en 1996 a fin de reducir el número creciente de litigios federales por parte de la población reclusa. Desde 1892, Act of fuly 20, ch. 209, 27 Stat. 252, todo ciudadano norteamericano puede acceder a los tribunales de los Estados Unidos aunque su pobreza le haga imposible costear los gastos. Es lo que se conoce como una acción in forma pauperis (IFP). Aplicado a los presos sin dinero suficiente, la ley les permite no pagar previamente las tasas o abonar sólo ciertos gastos. El caso es que la PLRA introdujo también aquí limitaciones cuando el preso había iniciado varias acciones. El contenido y alcance de estas medidas ha llegado a la USSC en los dos últimos años y de su respuesta dependen muchos casos relativos al libre ejercicio de la religión de los presos bajo la RLUIPA. En primer lugar, bajo la sección de la PLRA, 28 U.S.C. \$1915(g), conocida como los three strikes (no confundir con las leyes que aumentan las condenas en caso de reincidentes tras el tercer delito, las three strikes laws), para que un preso pueda acogerse al IFP, de tener varios procesos en curso, no le deben haber desestimado la acción civil, mientras estaba encarcelado o detenido, en tres o más ocasiones previas, por su carácter frívolo o malicioso, salvo peligro inminente de grave daño físico. Los circuitos no se ponían de acuerdo sobre si la 
desestimación de un caso, cuando aún estaba en apelación, entraba también dentro del cómputo de los tres. A diferencia de la mayoría de los circuitos y como antes hiciera el séptimo en el $2002^{56}$, el sexto dijo que sí en el año $2013^{57}$ y la USSC, en opinión del juez Breyer para un tribunal unánime, confirmó esa decisión el 18 de mayo en Coleman v. Tollefson, 135 S.Ct. 1759 (2015). En segundo lugar, la otra cuestión del IFP tenía que ver con el límite mensual del $20 \%$ a la hora del pago de las tasas. Según la PLRA, 28 U.S.C. \$1915(b), la acción in forma pauperis impone el pago de una parte del gasto en el momento de la presentación de la demanda y fija los pagos ulteriores hasta satisfacer el total en el 20\% de los ingresos mensuales del preso. Pero, ¿y si el preso se encuentra inmerso en diversos casos o apelaciones? No estaba muy claro si ese tope máximo debía aplicarse sobre el total de sus ingresos con independencia del número de casos (perprisoner approach), por lo que nunca sobrepasaría el 20\%, o si este límite se debía poner por cada litigio que mantuviera (per-case approach), es decir, llegando al $40 \%$ si tiene dos, al $60 \%$ si son 3 y al $100 \%$ de haber procedido en cinco ocasiones. No habiendo acuerdo entre los circuitos, el del Distrito de Columbia se inclinó por el de aplicación por casos, siguiendo el parecer de los circuitos quinto, séptimo, octavo y décimo ${ }^{58}$. El caso afectaba a cinco presos federales. La USSC aceptó el recurso de apelación el 15 de junio de 2015, discutió el caso 4 de noviembre y lo resolvió el 12 de enero del año siguiente por medio de una sentencia redactada por la juez Ginsburg confirmando la sentencia recurrida, inclinándose entonces por el criterio de aplicación del límite no sobre el total de los ingresos del preso sino por litigio, por casos.

Ross v. Blake, 136 S.Ct. 1850 (2015). El 11 de diciembre de 2015 la USSC resolvió por unanimidad un caso sin relación directa con el libre ejercicio religioso de un preso, aunque con repercusiones sobre litigios de esta naturaleza. Y es que, según la PLRA, para que un preso pudiera interponer una demanda judicial debía haber agotado previamente la vía administrativa. Pues bien, en la decisión recurrida que corregía la solución del tribunal de distrito,

${ }^{56}$ Cfr. Robinson v. Powell, 297 F.3d 540, at 541 [Posner, J.] (7th Cir., July 12, 2002). Para una relación de los circuitos en la opinión mayoritaria (primer circuito, segundo, tercero, quinto, octavo, noveno, décimo y el DC): Henslee v. Keller, 681 F.3d 538, at 541 [Gregory, J.] (4th Cir., June $5,2012)$.

57 Cfr. Coleman v. Tollefson, 733 F.3d 175 (6th Cir. Mich., October 23, 2013) y Coleman v. Tollefson, 2011 U.S. Dist. LEXIS 15228 (W.D. Mich., Feb. 15, 2011).

${ }^{58}$ Cfr. Pinson v. Samuels, 761 F.3d 1, at 7-8 [Srinivisan, J.] (DC Cir., August 5, 2014). 
el cuarto circuito había fallado a favor del preso al considerar satisfecha esa exigencia legal en «circunstancias especiales» cuando el demandante razonable, pero erróneamente, creía haberla agotado. La juez Kagan, encargada de redactar la decisión del Tribunal, reaccionó contra esta lectura que hacía el de apelación como algo inconsistente con el texto e historia de la ley federal por lo que anuló el fallo recurrido. Ahora bien, el preso no necesita agotar esa vía previa cuando el remedio administrativo no le fuera disponible. Los jueces Breyer y Thomas concurrieron parcialmente y el último en el juicio. El caso fue reenviado al cuarto circuito para proceder según lo dispuesto.

Ben-Levi v. Brown, 136 S.Ct. 930 (2016). El 29 de febrero de 2016 la USSC rechazó el recurso presentado en un caso en el que el cuarto circuito había respaldado la política penitenciaria de North Carolina que exigía la presencia de al menos diez reclusos, o de un rabino, para poder formar un grupo de estudio bíblico en la prisión. La cuestión es que a otros grupos religiosos no se imponía un número mínimo de miembros o un voluntario de fuera. Al tomar esta decisión parece que el departamento de prisiones había tenido en cuenta la doctrina religiosa del judaísmo. El juez Alito manifestó su desacuerdo con esta decisión del Supremo y no entendía cómo había sido posible negar al preso lo pedido basándose en la inadecuada comprensión de su propia religión, algo que según los tribunales inferiores no había lesionado su libre ejercicio religioso. Las pruebas demostraban justo lo contrario, sin que el departamento estatal hubiera podido probar un legítimo interés penitenciario para tratar los presos judíos con mayor rigor que los internos de otras religiones.

Knight v. Thompson, 136 S.Ct. 1824 (2016). El 2 de mayo de 2016 la USSC no quiso entrar a examinar un caso en el que el undécimo circuito había respaldado la decisión de un centro penitenciario de Alabama que, aplicando la normativa sobre aseo, había prohibido a presos nativos americanos llevar el pelo largo, aunque ello fuera por razones religiosas. Si podía ser verdad que el libre ejercicio de la religión de esos presos hubiera sido limitado de modo sustancial, también era cierto que el departamento estatal había probado la existencia de un poderoso interés estatal por razones de seguridad, disciplina y aseo, permitiendo una excepción de cabello corto como un medio menos restrictivo para lograr ese interés. No constaba en el caso discriminación de trato entre presos según su raza o religión. 
Ali v. Stephens, 822 F.3d 776 (5th Cir., May 2, 2016). A un preso musulmán de Texas el quinto circuito, confirmando la decisión recurrida, permitió, en ejercicio de sus derechos religiosos bajo la RLUIPA, el uso de barba de 10 centímetros así como de su gorro kufi en el centro penitenciario. El departamento estatal de Texas no había podido demostrar que su política penitenciaria en esta materia, con esa prohibición sobre la barba de los presos, fuera la medida menos lesiva para garantizar un poderoso interés estatal en combatir contrabando o evitar gastos; y en relación al kufi, no pudo probar que la prohibición fuera la medida menos restrictiva para lograr la identificación correcta del preso.

Knowles v. Pfister, 829 F.3d 516 (7th Cir., July 13, 2016). El séptimo circuito anuló aquí una decisión de un tribunal federal de distrito de Illinois permitiendo ahora a un preso neopagano Wicca llevar alrededor del cuello un medallón de una pulgada con una estrella plateada de cinco puntos en su interior. El centro penitenciario se lo había confiscado y ahora este tribunal de apelación concedía su uso, equiparando ese símbolo a la cruz de los cristianos.

United States v. Secretary, Florida Department of Corrections, 828 F.3d 1341 (11th Cir., July 14, 2016). El undécimo circuito defendió, bajo las exigencias de la RLUIPA, la entrega de comida Kosher a presos de Florida que la solicitaran por sus sinceras creencias religiosas sin que su negativa pudiera considerarse la medida menos restrictiva para lograr el interés estatal de contención de gastos cuando el Departamento federal de prisiones y otros Estados sí que ofrecían esa clase de comida a los presos, o cuando el departamento estatal sí proporcionaba otras dietas vegetarianas o terapéuticas con costes similares.

Crowder v. Lariva, 2016 U.S. Dist. LEXIS 122966 (SD IN, Sept. 12, 2016). Un tribunal federal de Indiana, en un caso en el que a un preso judío no se le autorizó dieta Kosher, sostuvo que, como preso federal que era, tenía una acción de reparación y resarcimiento de daños más amplia bajo la RFRA de 1993 que bajo la RLUIPA del 2000.

Hauseur v. Clark, 2017 U.S. Dist. LEXIS 13372 (ED CA, January 31, 2017). Un tribunal federal de distrito de California sostuvo que los presos de su Estado, además de las garantías reconocidas en la RFRA y RLUIPA, podrían también recurrir en sus demandas de libre ejercicio religioso a una ley estatal (California Bane Act, Civil Code Sec. 52.1) a fin de lograr una indemni- 
zación o reparación del daño causado cuando hubiera existido amenaza, intimidación o coacción. En este caso, un preso judío, que había denunciado los criterios sobre dieta Kosher y la negativa de ciertos servicios religiosos, había sufrido amenazas por parte de los funcionarios de la prisión de seguir negándole esos servicios si no retiraba sus denuncias. Un juez federal no quiso aplicar la normativa estatal de la Bane Act por no haber alegado el preso violencia o amenaza de violencia. En cambio, este tribunal federal juzgó suficientes las amenazas y coacciones sufridas.

Brown v. Bureau of Prissons, 2017 U.S. Dist. LEXIS 50227 (D CT, March 31, 2016). Un tribunal federal de Connecticut permitió a una mujer encarcelada, devota musulmana, que procediera bajo la RFRA en su denuncia contra el departamento de prisiones en un caso en el que había sido cacheada por un funcionario masculino sin circunstancias especiales que así lo exigieran. Una de las escasas denuncias de mujeres en centros penitenciarios. El caso fue desestimado por este tribunal federal por falta de claridad en la ley a aplicar a estas controversias cuando ni el Tribunal Supremo ni el de apelación o circuito había resuelto si ese cacheo estaba o no permitido. Si no era clara la solución, mientras tanto, los funcionarios gozaban de inmunidad cualificada, debiendo así ser desestimada la demanda.

McLenithan v. Williams, 2016 U.S. Dist. LEXIS 45290 (D OR, April 4, 2016). Un tribunal federal de distrito de Oregon rechazó aquí las denuncias de violación de libre ejercicio e igual protección bajo la RLUIPA de un preso al que se le había negado el acceso a una dieta Kosher. Se trataba de un adventista del séptimo día que practicaba el judaísmo como segunda religión. El posible coste que supondría abrir esa clase especial de dieta religiosa a presos no judíos justificaba el poderoso interés en limitar dicho alimento sólo a los judíos, ofreciendo en cambio a esos otros un tipo de comida diferente como medida menos restrictiva.

\section{ORaciones Legislativas}

American Humanist Association v. Birdville Independent School District, 137 S.Ct., nº 17-178 (filed July 31, 2017). El 31 de julio de 2017 le llegó a la USSC el recurso de apelación presentado en un caso en el que el quinto circuito acababa de respaldar en mayo la práctica de un departamento escolar que invita- 
ba a comenzar sus reuniones con presentaciones de estudiantes que, con frecuencia, incluían oraciones o plegarias. Para la solución del caso no siguió la doctrina sobre oración escolar sino la de las oraciones legislativas, según el precedente del Supremo en Town of Grace v. Galloway (2014). La presencia de los estudiantes no transformaba el caso en uno de oración escolar pues la mayoría de los asistentes en esas reuniones eran adultos, las plegarias tenían lugar en el momento introductorio o ceremonial de la reunión y la petición de levantarse no coaccionaba a la oración ${ }^{59}$.

Bormuth v. County of Fackson, 2017 U.S. App. LEXIS 17174 (6th Cir., Sept. 6, 2017). El sexto circuito se pronunció en banc a favor de la validez constitucional de ciertas invocaciones religiosas, prácticamente todas ellas cristianas, tenidas en la junta de representantes de un condado de Michigan por sus miembros elegidos, más que por un capellán o clérigo invitado, sin que ello supusiera ninguna amenaza a la garantía de no establecimiento religioso. En ningún caso se trataba de un acto en el que hubiera habido coacción o se estuviera respaldando una cierta religión, siendo muy diversas las confesiones cristianas de los miembros de la junta que allí habían participado.

\section{LIBERTAD DE EXPRESIÓN RELIGIOSA}

American Freedom Defense Initiative v. King County, Washington, 136 S.Ct. 1022 (2016). El 7 de marzo de 2016 la USSC rechazó la apelación de un caso de publicidad en autobuses que le había llegado del noveno circuito en el que, confirmando la sentencia recurrrida, había defendido el rechazo, razonable y neutral en foro no público, de una clase de publicidad que la agencia estatal de transporte del Estado de Washington (METRO) había juzgado falsa ${ }^{60}$. La asociación demandante quería poner en los buses un anuncio muy similar, aunque con información que no se ajustaba a la realidad, al que el Departamento de Estado había hecho tiempo antes con la cara de terroristas yihadistas buscados y la recompensa ofrecida por su captura. Un anuncio que había generado mucha polémica. El juez Thomas en el Supremo se opuso al rechazo del recurso en una opinión disidente a la que se sumó el juez Alito. A su jucio, el

${ }^{59}$ Cfr. American Humanist Association v. McCarty, 851 F.3d 521 (5th Cir., March 20, 2017).

${ }^{60}$ Cfr. American Freedom Defense Initiative v. King County, 796 F.3d 1165 (9th Cir., August 12, 2015). 
Tribunal estaba dejando escapar una oportunidad estupenda para pronunciarse sobre una cuestión en la que los tribunales de apelación (circuitos) no coincidían: si el espacio de publicidad creado en el caso de esos autobuses era un «limitado foro público» o un «designado foro público».

Cressman v. Thompson, 136 S.Ct. 1452 (2016). El 21 de marzo de 2016 la USSC rechazó la apelación presentada frente a una decisión del décimo circuito que se había pronunciado a favor de la constitucionalidad de una matrícula de automóvil estándar que el Estado de Oklahoma empleaba y en la que figuraba un indio nativo americano disparando una flecha al cielo. Para el demandante cristiano monoteísta, esa imagen, según las creencias indígenas, representaba la conexión del hombre con los dioses a través de la mediación de la flecha. Esto le obligaba entonces a comunicar un mensaje panteísta con el que no podía estar de acuerdo, algo contrario a su derecho de libertad de expresión. Sin embargo, el tribunal de apelación no lo vio así porque la imagen primero no era propiamente una idea o expresión de ella y segundo porque no suponía más que un recuerdo de la cultura y herencia del pueblo nativo americano de Oklaho$\mathrm{ma}^{61}$. Pero éste no fue el único caso en el que se vieron implicadas las matrículas de los coches durante estos últimos años. Así, por ejemplo, «American Civil Liberties Union, ACLU» $\mathrm{y}$ «Freedom From Religion Foundation», en Hart $v$. Thomas, no 3:16-cv-00092-GFVT (ED KY, filed November 22, 2016), denunciaron por discriminatorio al departamento estatal de Kentucky encargado de conceder la autorización de las matrículas especiales cuando rechazó la presentada por un ateo que deseaba figurara en ella las letras «IM GOD». El departamento no la permitió por entender que era ofensiva al buen gusto y decencia.

Wayne County v. Bible Believers, 136 S.Ct. 2013 (2016). El 16 de mayo de 2016 la USSC no quiso entrar en un caso en el que el sexto circuito en banc había fallado a favor de un grupo cristiano (Bible Believers) que en un festival de Michigan lleno de musulmanes («Michigan Arab International Festival») se había dirigido a ellos con ánimo proselitista en una actitud provocadora y ofensiva. Los ayudantes del sheriff se lo impedieron por la reacción hostil que provocó en la multitud y, al hacerlo, violaron sus derechos de libertad de expresión y libre ejercicio de la religión ${ }^{62}$. Pues bien, ese mismo día, el 16 de

${ }^{61}$ Cfr. Cressman v. Thompson, 798 F.3d 938 (10th Cir. Okla., August 4, 2015).

${ }^{62}$ Cfr. Bible Believers v. Wayne County, 805 F.3d 228 (6th Cir., October 28, 2015). 
mayo, el Supremo también rechazó, en Rogers v. Roman Catholic Archbishop of Boston, 136 S.Ct. 2013 (2016), el recurso que le llegó de un tribunal estatal de apelación de Massachusetts que había prohibido a los antiguos fieles de una parroquia católica seguir ocupando la iglesia desacralizada. Esos feligreses lo llevaban haciendo los últimos diez años con vigilias de 24 horas, desde que el Cardenal Seán O'Malley decidiera cerrar la Iglesia dentro del plan de reorganización de su Diócesis ${ }^{63}$.

En el mes de agosto de 2016 se alcanzó un acuerdo que cerró el litigio (American Atheists, Inc. v. Watson, ED TN, filed May 6, 2016) entre un condado de Tennessee y una asociación de ateos (American Atheists) por los comentarios cristianos del sheriff Watson del condado de Bradley vertidos en la página oficial de «Facebook». El acuerdo llegó cuando el condado aceptó el pago de 15.000 dólares en daños a la asociación y otros 26.000 para cubrir los honorarios de abogados. Además el sheriff se había comprometido a cancelar la página web y crear una nueva sin referencia religiosa alguna, quedando a salvo la página personal del sheriff en la que pueda incluir todas las opinones personales que quisiera ${ }^{64}$.

Fort Des Moines Church of Christ v. Fackson, 215 F. Supp. 3d 776 (SD IA, Oct. 14, 2016). En medio de la guerra surgida en el acceso a los baños por las personas transgénero, el 14 de octubre de 2016 un tribunal federal de distrito de Iowa respaldó la normativa estatal contraria a la discriminación en razón de la identidad de género en lugares de pública admisión como era una iglesia en este caso. Las leyes permitían excepciones ante actos religiosos de esas instituciones pero la iglesia deseaba publicar en su website y en el boletín parroquial su política de limitar el uso de los baños según la identidad biológica del sujeto, tal y como ésta figurara en el certificado de nacimiento. El tribunal rechazó el argumento de libertad de expresión de la demandante por lo muy improbable que la normativa se impusiera sobre sus actividades, todas ellas religiosas, ante la excepción presente en ellas. Y también rechazó su argumento de libre ejercicio religioso contra la normativa estatal por entender que ésta era neutral y de general aplicación.

${ }^{63}$ Cfr. Roman Catholic Archbishop of Boston v. Rogers, 88 Mass. App. Ct. 519 (MA App., October 14, 2015).

${ }^{64}$ Cfr. https://www.atheists.org/2016/08/atheists-reach-41000-settlement-with-tennessee-countysheriff/. 
Payden-Travers v. Talkin, 2017 U.S. Dist. LEXIS 82466 (D DC, May 31, 2017). En este caso, un tribunal federal de distrito de DC rechazó la petición de los demandantes contra la normativa que prohibía manifestarse en el área delante del edificio del Tribunal Supremo. Para ellos, su fe les exigía expresarse públicamente en contra de la guerra, tortura y pena de muerte, de modo que hacerlo en la acera, pero no en la plaza, como sí se les concedía, no permitía conectar con claridad sus objeciones con las acciones del Tribunal. A su juicio, esto les suponía una violación de sus derechos de libre ejercicio religioso bajo la RFRA. Por el contrario, para este tribunal de distrito, las acciones denunciadas no limitaban sustancialmente su libre ejercicio pues no habían demostrado que su religión exigiera, como parte de la misma, esa conexión de su protesta con el Tribunal Supremo, teniendo además a su alcance otras muchas vías para mostrar públicamente su disconformidad.

Matal v. Tam, 137 S.Ct. 1744 (2017). Una ley del Congreso de 1946, Lanham Act, permitía al gobierno («Patent and Trademark Office») negar el registro de aquellas marcas que pudieran suponer un desprecio hacia las personas, vivas o muertas, hacia instituciones, creencias (políticas, ideológicas o religiosas) o símbolos nacionales, o bien hacerles perder su fama o respeto hacia ellas. Esto planteó la cuestión del alcance de la libertad de expresión y de la protección de la religión frente a la blasfemia que fue el objeto de este caso que le llegó al Supremo desde un tribunal de apelación para el ciruito federal de 22 de diciembre de $2015^{65}$. El recurso de apelación al Supremo fue aceptado el 29 de septiembre de 2016 y la discusión del caso tuvo lugar el 18 de enero de 2017. Aquí, la agencia gubernamental había rechazado el registro de la marca «The Slants» para una banda de rock por el uso despectivo que, en el lenguaje vulgar (slang), se hacía de esa expresión para designar a los asiáticos. El tribunal de apelación falló en contra del gobierno porque suponía una clara violación de la cláusula de libertad de expresión de la Primera Enmienda y el Supremo le dio la razón porque precisamente lo que impedía esa libertad era prohibir aquello que podía ofender. La opinión unánime de la USSC quedó reflejada en una sentencia redactada por el juez Alito con apartados diversos en los que fueron sumándose el resto de los jueces sin la intervención de Gorsuch. Así pues, en relación a la libertad religiosa, queda abierta la posibilidad de registrar marcas que puedan resultar ofensivas para personas e instituciones religiosas.

${ }^{65}$ Cfr. In re Tam, 808 F.3d 1321 (Fed. Cir., Dec. 22, 2015). 


\section{Simbología ESTÁTICA: DeCÁLOGOS y CRUCES}

City of Bloomfield v. Felix, no 17-60 (2017). El 6 de julio de 2017 fue recurrida a la USSC la sentencia del décimo circuito que había rechazado en banc, con el desacuerdo de dos jueces, la revisión de un caso en el que un panel de tres jueces había sostenido con anterioridad que el Decálogo situado en el jardín del ayuntamiento de una ciudad de New Mexico era inconstitucional como algo contrario a la garantía de separación exigida por la cláusula del no establecimiento. En el recurso presentado se le plantearon al Supremo dos cuestiones: primero, los criterios que deben seguirse a la hora de evaluar los símbolos estáticos como son los monumentos; y segundo, si es suficiente criterio para tener legitimación activa al denunciar estos monumentos el sentirse ofendidos por ellos. Pues bien, el Decálogo fue denunciado en este caso por unos residentes politeístas de la ciudad y el décimo circuito dijo que enviaba un claro mensaje de respaldo religioso a todo «observador razonable» por el lugar en el que se encontraba, por las circunstancias que rodeaban su inauguración, y por su financiación. Ni la presencia de otros monumentos seculares ni las declaraciones en contra habían sido suficientes para superar esa impresión ${ }^{66}$. Pues bien, el 25 de septiembre trece escritos en defensa de la posición de la demandante habían sido registrados ante la USSC, frente al único en apoyo de las tesis de la demandada. No importó el número porque el 16 de octubre el recurso de apelación fue rechazado por el Supremo. Pero ésta no fue la única polémica planteada en relación a un Decálogo.

El 7 de abril de 2015 el legislador de Arkansas aprobó la «Ten Commandments Monument Display Act» (SB 939), una ley por la que se comisionaba al Secretario de Estado para la búsqueda de fondos privados a fin de poder colocar un Decálogo en el congreso de Arkansas. Un año después, en agosto de 2016, la «American History and Heritage Foundation» solicitó a esa Secretaría la colocación de un monumento de casi dos metros de altura y unos 2.700 kilos. Se trataba de un Decálogo muy parecido al que Texas había colocado en su Congreso y que había permitido la USSC en Van Orden v. Perry (2005). Tras consultar el Secretario con la comisión estatal correspondiente («Capitol Arts and Grounds Commission»), el monumento fue levantado finalmente el 27 de junio de 2017 y el senador estatal que respaldó la iniciativa dijo que por fin ya había

${ }^{66}$ Cfr. City of Bloomfield v. Felix, 841 F.3d 848 (10th Cir., November 9, 2016). En banc, el mismo circuito se negó a reabrir el caso en City of Bloomfield v. Felix, 847 F.3d 1214 (10th Cir., February 6, 2017). 
en el Capitolio un monumento que honraba la fundación moral de la ley, sin haberle costado nada al contribuyente. Por su parte, la ACLU dijo que llevaría el Decálogo a los tribunales a fin de ser removido. No pasaron ni 24 horas antes que un hombre lo destrozara con su coche, parece que el mismo sujeto que tres años antes había destrozado del mismo modo el monumento a los Diez Mandamientos de Oklahoma. Un nuevo Decálogo fue ordenado inmediatamente.

El 28 de septiembre de 2017, un tribunal federal de Pennsylvania, en Freedom From Religion Foundation, Inc., v. County of Lebigh, 2017 US Dist. LEXIS 160234 (ED PA, Sept. 28, 2017), sostuvo que la presencia de una cruz latina en el sello y bandera de un condado de ese Estado no violaba la separación entre Iglesia y Estado que garantizaba la cláusula de no establecimiento de la Primera Enmienda pero sí los criterios del lemon test (faltaba el propósito secular de la medida) y del endorsement test (enviaba un mensaje de respaldo religioso a un observador medio, razonable). Para el juez Smith, la cruz en el sello y bandera era un símbolo pasivo que ni obligaba a nadie a adherirse al cristianismo ni establecía esa religión.

\section{Trabajo}

Es sabido que además de la garantía constitucional de igual protección de la Decimocuarta Enmienda, el Título VII de la Civil Rights Act de 1964, 42 U.SC. $\$ 2000$ e, prohíbe toda discriminación en el trabajo por razón de raza, color, religión, sexo y origen nacional (\$2000e-2 [a]). Por religión la ley entiende todo aspecto de observancia y práctica religiosa, así como de creencia. El empresario debe ofrecer una adaptación razonable del ejercicio religioso (\$2000e[j]). Desde el 2 de julio de 1965, la Equal Employment Opportunity Commission (EEOC) es la agencia federal encargada de hacer cumplir la ley en la materia, evitando la discriminación en el mundo del trabajo.

Sin tener que ver directamente con la religión, aunque presente en el fondo de muchos casos, la principal cuestión surgida en estos años ha tenido que ver con la discriminación por razón de sexo, tras la discrepancia entre la EEOC y el Departamento de Justicia en esta materia ${ }^{67}$, siendo así que unos tribunales

${ }^{67}$ En este sentido pueden compararse los escritos presentados en direcciones contrarias en el caso Zarda v. Altitude Express, Inc., 2017 U.S. App. LEXIS 13127 (2nd Cir., May 25, 2017): la posición del USDOJ, en http://lc.org/072717Zarda-DOJ-brief.pdf y la de la EEOC, en https://assets.documentcloud.org/documents/3900222/Zarda-v-Altitude-Express-EEOC-Amicus-2nd.pdf. 
han querido incluir dentro del campo de comprensión del Título VII la orientación sexual y otros no. Entre los primeros: U.S. Equal Employment Opportunity Commission v. Scott Medical Health Center, 217 F. Supp. 3d 834 (WD PA, Nov. 4, 2016); Hively v. Ivy Tech Community College of Indiana, 853 F.3d 339 (7th Cir., April 4, 2017); Christiansen v. Omnicom Group, Inc., 852 F.3d 195 (2nd Cir., March 27, 2017). Partidarios de la exclusión de la orientación sexual del marco de la discriminación por razón de sexo han sido: Christiansen v. Omnicom Group, Inc., 167 F. Supp. 3d 598 (SD NY, March 9, 2016); Hively v. Ivy Tech Community College, 830 F.3d 698 (7th Cir., July 28, 2016); Matavka v. Board of Education of 7. Sterling Morton High School District 201, 2016 U.S. Dist. LEXIS 100108 (N.D. Ill. 2016, Aug. 1, 2016); Evans v. Georgia Regional Hospital, 850 F.3d 1248 (11th Cir., March 10, 2017); State of West Virginia v. Butler, (Sup. Ct. WV, May 9, 2017). Un tribunal federal de distrito de Kentucky, en Mickens v. General Electric Co., 2016 U.S. Dist. LEXIS 163961 (WD KY, November 29, 2016), ha creido incluidas, dentro del Título VII y de la discriminación por razón de sexo, a las personas transgénero, en este caso un trabajador afroamericano. No lo vio de la misma manera un tribunal federal de distrito de Michigan cuando negó que el transgénero fuera una clase protegida bajo el Título VII de la Civil Rights Act. En EEOC v. R.G. \& G.R. Harris Funeral Homes, Inc., 100 F. Supp. 3d 594 (ED MI, April 21, 2015) el tribunal sostuvo esta tesis aunque permitió al EEOC, sobre la base del estereotipo sexual, proceder en la causa de despido del trabajador de la funeraria por no cumplir con el código de vestuario previsto para los trabajadores masculinos. Más tarde, el 18 de agosto de 2016 en EEOC v. R.G. \& G.R. Harris Funeral Homes, Inc., 201 F. Supp. 3d 837 (ED MI, 2016), este mismo tribunal acogió el argumento de libertad religiosa ofrecido por la empresa bajo la RFRA pues permitir al trabajador (hombre en proceso de cambio de identidad de género a mujer) no respetar el código de la funeraria hacía participar a ésta en un mensaje contrario a sus creencias. El dueño del negocio como cristiano que era creía que la identidad de género era un regalo inmutable que Dios daba a los hombres en su concepción, de suerte que de permitir a sus trabajadores actuar de modo distinto al sexo recibido estaría violando un mandato divino. El tribunal dijo que la EEOC podía tener un interés poderoso en evitar discriminación pero no había ofrecido a la empresa una adaptación razonable que fuera la medida menos restrictiva, lo que se hubiera satisfecho con un código neutral de vestido. El sexto circuito discutió el caso en apelación el miércoles 4 de octubre de 2017. Veremos el recorrido que presenta el caso en los próximos meses. Por su par- 
te, el fiscal general Jeff Sessions, ese mismo día, 4 de octubre, dos antes del Memorándum del Departamento de Justicia en orden a la protección de la libertad religiosa, corrigió la política de la administración Obama afirmando sin lugar a dudas que el Título VII de la Civil Rights Act no incluía entre sus protecciones la discriminación en el caso de las personas transgénero.

CRST Van Expedited, Inc. v. EEOC, 136 S.Ct. 1642 (2016). La USSC anuló la decisión recurrida del octavo circuito y sostuvo el 19 de mayo de 2016 en esta sentencia unánime, redactada por el juez Kennedy con una opinión concurrente de Thomas, que, en aquellos casos de discriminación en el empleo, los acusados que hubieran ganado el caso, fuera tanto por razones procesales como sustanciales (sobre el fondo o mérito del asunto discutido), tendrían derecho a recuperar los honorarios de los abogados. En uno y otro caso serían considerados parte vencedora (prevailing party) a estos efectos. El octavo circuito defendía que lo fueran sólo cuando el tribunal entrara en el fondo del asunto y fallara a su favor. El caso, como se puede ver, tendrá notable repercusión sobre los litigios de discriminación religiosa en el mundo del trabajo.

McLane Co. v. EEOC, 137 S.Ct. 1159 (2017). La juez Sotomayor para una mayoría 7 a 1, con el voto parcialmente disidente de la juez Ginsburg, resolvió, en un caso de discriminación por razón de sexo y edad en el despido de una trabajadora tras un permiso de maternidad, que los tribunales de apelación no debían revisar de novo las órdenes de apercibimiento dadas por los tribunales inferiores de distrito para conseguir las pruebas necesarias cuando la EEOC no las hubiera logrado de la empresa y se hubiera dirigido así al tribunal en busca de ellas. Esa revisión de la decisión del tribunal inferior sólo debía ocurrir en caso de abuso de discreción. Con este criterio mostraba el Supremo una actitud deferente que no había respetado el noveno circuito, fallo que fue anulado aquí ${ }^{68} \mathrm{y}$ reenviado el caso para que procediera según lo dispuesto. Al volver al noveno circuito, este tribunal encontró que la revisión de la orden dada por el tribunal inferior de distrito había sido pertinente pues el de distrito había abusado de su discreción al excluir una prueba que sí era relevante para la solución del litigio ${ }^{69}$. De nuevo este caso tendrá su importancia también en los casos de discriminación religiosa en el empleo.

${ }^{68}$ Cfr. United States EEOC v. McLane Co., 804 F.3d 1051 (9th Cir., Oct. 27, 2015).

${ }^{69}$ Cfr. United States EEOC v. McLane Co., 857 F.3d 813 (9th Cir., May 24, 2017). 


\section{EjÉRCITO}

Klingenschmitt v. United States, 137 S.Ct. 93 (2016). El lunes 3 de octubre de 2016, comienzo del año judicial, la USSC rechazó el recurso presentado frente a una sentencia del tribunal federal de apelación que había resuelto en contra de la reclamación presentada por un capellán militar que servía a la Armada. Gordon James Klingenschmitt era un ministro cristiano al que no se le quiso renovar en el servicio, después de perder el respaldo de la iglesia episcopal y sin ser admitidas directamente las credenciales que había conseguido de otra confesión cristiana, amén de otras deficiencias en el ejercicio de su trabajo como saltarse la cadena de mando, de informes negativos que fueron reflejándose en informes anuales de aptitud cada vez peores, así como de su resistencia a seguir la política del departamento de defensa sobre oraciones inclusivas y más «ecuménicas» de lo que acostumbraban ser sus sermones, parece que demasiado cristianos ${ }^{70}$.

Sterling v. United States, 137 S.Ct. 2212 (2017). El 5 de junio de 2017 la USSC no quiso entrar tampoco en un caso en el que a una militar cristiana no se la había permitido poner en su escritorio, espacio de trabajo compartido, ciertos signos que contenían citas bíblicas. El tribunal federal de apelación para las fuerzas armadas dijo que el caso no era claro desde que la demandante no había logrado identificar con claridad sus sinceras creencias religiosas, ni cómo la eliminación de unas citas (del estilo de «ningún arma contra mí prosperará» en el contexto de un enfrentamiento personal con sus superiores) limitaba sustancialmente su ejercicio religioso bajo la $\mathrm{RFRA}^{71}$. En apelación se pidió al Supremo pronunciarse sobre la cuestión de si una elección forzada entre la religión y el mandato del gobierno era necesaria o no para establecer un límite sustancial bajo esa ley. Pero la USSC no quiso entrar en el asunto.

En cualquier caso, la polémica más importante en la esfera de las fuerzas armadas ha tenido que ver con la política del departamento de defensa sobre los militares transgénero. El 30 de junio de 2016 el tercero de los Secretarios de Defensa bajo la administración Obama, Ashton Carter (25 Ministro de Defensa, en el cargo del 17 de febrero de 2015 al 20 de enero de 2017), anunció,

\footnotetext{
${ }^{70}$ Cfr. Klingenschmitt v. US, 623 Fed. Appx. 1013 (Fed. Cir., December 10, 2015); Klingenschmitt v. US, 119 Fed. Cl. 163 (Fed. Cir., November 24, 2014).

${ }^{71}$ Cfr. United States v. Sterling, 75 M.J. 407 (C.A.A.F., Aug. 10, 2016).
} 
en la línea LGTB de Obama, que se levantaría la prohibición de servir en el ejército a las personas transgénero ${ }^{72}$. Los que estuvieran dentro podrían hacer pública su condición, como años atrás se había permitido con los gays hasta entonces reprimidos bajo el famoso axioma «Don't ask, don't tell (DADT)», y recibir el tratamiento adecuado a la transición de género si lo necesitaran ${ }^{73}$. Fue entonces cuando un grupo de capellanes hicieron ver los problemas de conciencia que podría crear esta medida ${ }^{74}$. El cambio de administración en la Casa Blanca con la llegada de Donald Trump a la presidencia alteró esta situación. En uno de sus famosos tweets a finales de julio de 2017 el presidente dijo que, tras consultar con generales y expertos militares, el ejército no aceptaría más ni permitiría el servicio de personas transgénero, cuando todos los esfuerzos debían destinarse a la victoria de sus batallas sin consentir el freno que supondrían esta clase de personas ${ }^{75}$. Un mes después, el 25 de agosto, Trump publicó un Memorándum dirigido a los Secretarios de Defensa y de «Homeland Security» en el que daba a conocer la nueva dirección emprendida por su administración ${ }^{76}$. Para el presidente Trump era necesario volver a la antigua política, antes del cambio operado por Obama, para no permitir el alistamiento en el Ejército de personas transgénero a partir del 1 de enero de 2018 y, en relación a las que hubiera, se detendrá el desvío de fondos para los procesos quirúrgicos de reasignación de sexo a partir del 23 de marzo de 2018,

${ }^{72}$ Nos remitimos aquí a rueda de prensa de Ash Carter y del informe publicado en la web del Departamento: https://www.defense.gov/News/Article/Article/822235/transgender-service-members-can-now-serve-openly-carter-announces/; https://www.defense.gov/News/Special-Reports/0616_transgender-policy/.

73 Cfr. https://www.defense.gov/Portals/1/features/2016/0616_policy/Transgender-Implementation-Fact-Sheet.pdf.

${ }^{74}$ Cfr. http://www.chaplainalliance.org/site/wp-content/uploads/2016/07/2016-07-06-ChaplainAlliance-News-Release.pdf.

${ }^{75}$ La reacción a esta declaración de intenciones fue la presentación de una demanda por cinco militares como discriminatoria y arbitraria contra los derechos de las personas transgénero en Doe v. Trump, 17-cv-1597 (D DC, filed August 9, 2017): https://assets.documentcloud.org/documents/3921870/Jane-Doe-Lawsuit.pdf.

${ }^{76}$ Cfr. Presidential Memorandum for the Secretary of Defense and the Secretary of Homeland Security (Agust 25, 2017), en https://www.whitehouse.gov/the-press-office/2017/08/25/presidential-memorandum-secretary-defense-and-secretary-homeland. La respuesta no se hizo esperar y una demanda fue presentada ante un tribunal federal del Estado de Washington cuando tres particulares y dos grupos en defensa de derechos civiles denunciaron en Karnoski v. Trump, No. 2:17cv-1297 (WD WA, filed August 28, 2017) la constitucionalidad de la medida por contravenir las garantías de igualdad y proceso justo de la Quinta Enmienda y libertad de expresión de la Primera, cfr. https://www.lambdalegal.org/sites/default/files/legal-docs/downloads/karnoski_us_ 20170828_complaint.pdf. 
salvo en aquellos casos en los que fueran necesarios para proteger la salud de alquien que ya lo hubiera iniciado. El nuevo Secretario del Departamento de Defensa, James M. (Jim) Mattis, hizo saber el 29 de agosto que, para mejor cumplir las indicaciones del presidente Trump, se crearía un panel de expertos que evaluaran lo necesario para conseguir el fin del ejército, su eficacia en el combate para la victoria en el campo de batalla. Mientras tanto la política en la materia seguiría igual que estaba ${ }^{77}$.

\section{INMIGRACIÓN Y SEgURIDAD}

Trump v. International Refugee Assistance Project, 137 S.Ct. 2080 (2017). El 26 de junio de 2017 la USSC, en una opinión per curiam, levantó la prohibición parcial que impedía el cumplimiento de la segunda orden ejecutiva de Trump de 9 de marzo de 2017 (Executive Order No. 13780, \$\$2[c] and 6[a] and [b], 82 Fed. Reg. 13209) que, sobre la estela de la anterior (las dos conocidas como la «Muslim ban» del presidente Trump), en materia inmigratoria y de seguridad, suspendía durante 90 días la entrada en el país a los nacionales de seis países de mayoría musulmana (Irán, Libia, Somalia, Sudán, Siria y Yemen) por razones de interés nacional ante el alto riesgo terrorista que existía. Un tribunal federal de distrito y el cuarto circuito habían decidido paralizar la ejecución de la orden presidencial por violar la garantía constitucional de separación contenida en la cláusula religiosa de no establecimiento de la Primera Enmienda.

En los primeros días al frente de la Casa Blanca, Donald Trump firmó una primera orden ejecutiva el 27 de enero de 2017, la Protecting the Nation From Foreign Terrorist Entry Into the United States Executive Order, No. 13.769, 82 Fed. Reg. 8977 (Feb. 1, 2017). El presidente pidió en esta orden de enero a los Secretarios de los Departamentos de «Homeland Security» y de Estado que evaluaran si eran suficientes los mecanismos existentes para detectar la presencia de extranjeros peligrosos que quisieran entrar en el país para hacerle daño. Mientras tanto se prohibiría, sección 3 (c) de la orden, la entrada durante tres meses (90) días a los nacionales de siete países (en esta orden de enero también figuraba en la lista Irak), todos ellos musulmanes. Por otra parte, en el caso de los refugiados, sección 5, la orden presidencial suspendía su en-

77 Cfr. Statement by Secretary of Defense Fim Mattis on Military Service by Transgender Individuals (August 29, 2017), en https://www.defense.gov/News/News-Releases/News-Release-View/Article/ 1294351/statement-by-secretary-of-defense-jim-mattis-on-military-service-by-transgender/. 
trada en el país por un periodo de 120 días y en el caso de los sirios por tiempo indefinido. En todo caso, los refugiados perseguidos por razones religiosas tendrían prioridad (sección 5 [b]). Trump estaba pensando en los cristianos martirizados en el Medio Este y en especial en Siria, según dijo en una entrevista que le hiciera $C B N$ News el 30 de enero ${ }^{78}$. La reacción de la ACLU no tardó, apuntando a lo que sería una de las acusaciones recurrentes contra la decisión presidencial: tomar como criterio una religión sobre otra ponía en riesgo la separación debida entre Iglesia y Estado ${ }^{79}$. Una de las primeras denuncias contra la orden, por violación del no establecimiento, tuvo lugar en un tribunal federal de California: People of the United States of America and the State of California v. Trump, Case $\mathrm{n}^{\mathrm{o}}$ 3:17-cv-451 (ND CA, filed January 28, 2017). Y el «Council on American-Islamic Relations» (CAIR) anunció su intención de denunciar, en representación de un grupo de más de 20 individuos, la validez constitucional de la medida en un tribunal federal de Virginia pues el objetivo de la orden era evitar que los nacionales musulmanes de países de mayoría de esa confesión entraran en Estados Unidos ${ }^{80}$ : amenaza cumplida en Sarsour v. Trump, Case $\mathrm{n}^{\circ}$ 1:17 cv00120 (ED VA, filed January 30, 2017) cuando denunció la validez de la orden ejecutiva como contraria al libre ejercicio de la religión y al no establecimiento ${ }^{81}$. El 1 de febrero de 2017 la sección consular de la embajada norteamericana en Tel Aviv dijo que los viajeros con un visado válido en su pasaporte de Israel, aunque fueran originarios de esos países incluidos en la lista de la orden presidencial, podrían viajar a Estados Unidos sin problemas, quedando la entrada, como siempre, a jucio final del agente de aduanas ${ }^{82}$.

${ }^{78} \mathrm{La}$ entrevista puede seguirse en la web de la CBN: http://www1.cbn.com/cbnnews/politics/2017/ january/president-trump-to-sit-down-with-news-for-exclusive-interview-friday.

79 Cfr. D. Cole, We'll See You in Court: Why Trump's Executive Order on Refugees Violates the Establishment Clause (January 28, 2017), en https://www.aclu.org/blog/national-security/discriminatory-profiling/well-see-you-court-why-trumps-executive-order? redirect=blog/speakfreely/well-see-you-court-why-trumps-executive-order-refugees-violates-establishment.

${ }^{80}$ Cfr. CAIR to Announce Constitutional Challenge to Trump's 'Muslim Ban' Executive Order, en https://www.cair.com/press-center/press-releases/14062-cair-to-announce-constitutional-challenge-to-trump-s-muslim-ban-executive-order.html.

${ }^{81}$ Este tribunal se pronunció sobre la garantía de no establecimiento cuando la orden ejecutiva de enero había sido revocada por la segunda de marzo. En relación a esta última, el tribunal federal de Virginia dijo que los demandantes, denunciando que la orden presidencial trataba desfavorablemente al islam, no habían probado una violación de esa garantía: Sarsour v. Trump, 2017 U.S. Dist. LEXIS 43596, at 24-34 [Trenga, J.] (ED VA, March 24, 2017).

82 Cfr. Message from US Embassy Tel Aviv Consular Section, en https://il.usembassy.gov/visas/message-u-s-embassy-tel-aviv-consular-section/. 
Pues bien, esta primera orden presidencial de enero de 2017 provocó una avalancha de denuncias en diversos tribunales. El 3 de febrero un tribunal federal de Washington paralizó el cumplimiento de la orden en Washington $v$. Trump, 2017 U.S. Dist. LEXIS 16012 (WD WA., 2017), aunque no por razones de establecimiento religioso (sí hablaba de efectos perjudiciales en el área del empleo, de la educación, de los negocios, de las relaciones familiares o de la libertad de circulación) cuando existía cierta discrepancia sobre la violación o no de éste ${ }^{83}$, y días después el noveno circuito per curiam, en Washington $v$. Trump, 847 F.3d 1151 (9th Cir., February 9, 2017), no quiso detener la prohibición sobre la orden mientras durara la apelación; su argumentación giró sobre la cláusula del proceso justo de la Quinta Enmienda sin entrar tampoco ahora en la cuestión del no establecimiento y la discriminación religiosa ${ }^{84}$. Como consecuencia de esta decisión del noveno circuito, el presidente Trump, tras la recomendación del fiscal general y del Secretario de «Homeland Security», decidió emitir una nueva orden ejecutiva, la segunda (EO-2: Executive Order No. 13.780, 82 Fed. Reg. 13.209 [Mar. 9, 2017]), a principios de marzo que, revocando la primera de enero y corrigiendo posibles defectos, fijaba su entrada en vigor para el 16 de marzo. La sección 2(c) de la nueva orden ejecutiva suspendía la entrada en Estados Unidos de los nacionales de aquellos seis países (Irak cayó de la lista ante la colaboración del gobierno iraquí y se decía de esas seis naciones restantes que respaldaban o patrocinaban el terrorismo, que mantenían vínculos con organizaciones terroristas o que contenían zonas de conflicto activo) mientra se evaluaba si estaban ofreciendo información adecuada para la prevención de la infiltración en America de terroristas infiltrados. Y, mientras tanto, la orden prohibió nuevamente la entrada durante 90 días de esos extranjeros aunque clarificando ahora, tras las observaciones planteadas en diveros tribunales, que esta suspensión de entrada afectaría: únicamente a los extranjeros de esos seis países que estuvieran fuera de Estados Unidos en el momento de la entrada en vigor de la orden (16 de marzo de 2017), carecieran a esa fecha de un visado válido y no tuvieran ésta en la fecha de la orden de enero. La suspensión de la entrada no afectaría a los residentes permanentes legales y figuraba también un examen indi-

83 Por ejemplo, en Loubghalam v. Trump, 230 F. Supp. 3d 26, at 35 [Gorton, J.] (D MA, February 3, 2017). Sin embargo, en Aziz v. Trump, 234 F. Supp. 3d 724, at 733-737 [Brinkema, J.] (ED VA, Feb. 13, 2017), otro tribunal federal, esta vez de Virginia, sí creyó ver posibilidades de éxito en el capítulo de la establishment clause.

${ }^{84}$ Cfr. Washington v. Trump, 847 F.3d 1151, at 1168 (9th Cir., February 9, 2017). 
vidualizado allí donde negar la entrada causara un daño o dificultad excesiva sin amenaza para la seguridad nacional o fuera en interés nacional. La nueva orden fijaba incluso un elenco no exhaustivo de circunstancias en las que la entrada en Estados Unidos pudiera ser considerada apropiada como podría ser el caso de un familiar cercano (esposo, hijo o padre) de un ciudadano norteamericano, de un residente permanente legal o de un extranjero que hubiera entrado con un visado válido. Pues bien, dos tribunales federales, uno en $\mathrm{Ha}$ waii, el 15 de marzo, y otro en Maryland, al día siguiente, se pronunciaron en contra de la EO-2, mientras que uno de Virginia, el 24 de marzo, la sostuvo ${ }^{85}$. En el caso de Hawaii, ese tribunal transformó su primera decisión de paralizar la ejecución de la orden presidencial en una probibición de hacerlo (de una TRO, «temporary restraining order», a lo que se conoce en derecho norteamericano como una preliminar injunction), ante la posibilidad de éxito de los demandantes en su alegación de establecimiento religioso bajo el primero de los elementos del Lemon test, es decir, el propósito secular de la ley ${ }^{86}$. Esta decisión fue recurrida al noveno circuito que discutió el caso el 15 de mayo, fallando per curiam el 12 de junio, en State of Hawaii v. Trump, 859 F.3d 741 (9th Cir., June 12,2017), parcialmente a favor de la prohibición de la segunda orden presidencial EO-2 (en contra de las dos principales medidas incluidas en la sección 2 [c] y 6 [a] y [b]), sin entrar en el fondo del argumento del no establecimiento religioso sino por contravenir la Inmigration and Nationality Act (INA) de 1952, Pub. L. 82-414, 66 Stat. 163, al exceder la orden la autoridad del Presidente bajo dicha la ley, discriminando sobre criterios de nacionalidad. Antes, el 25 de mayo, el cuarto circuito, International Refugee Assistance Project v. Trump, 857 F.3d 554 (4th Cir., May 25, 2017), también había mantenido en

${ }^{85}$ Cfr. State of Hawaii v. Trump, 241 F. Supp. 3d 1119, at *31 [Watson, J.] (D HI, March 15, 2017). La reacción del Presidente Trump fue el anuncio del recurso de esta sentencia al Supremo. El 3 de febrero de 2017 ese tribunal había recibido la primera demanda contra la anterior versión de la orden presidencial de enero por razones de establecimiento religioso y el 14 de ese mes el fiscal general anunció que el juez del caso había permitido añadir alegaciones de libre ejercicio bajo la RFRA. Por su parte, en Maryland, otro tribunal federal de distrito, en International Refugee Assistance Project v. Trump, 241 F. Supp. 3d 539, at *54 [Chuang, J.] (D MD, March 16, 2017) prohibió la ejecución de la orden presidencial, con similares argumentos. En este caso la demanda había sido introducida el 7 de febrero contra la primera versión de la orden presidencial sobre argumentos de no establecimiento religioso, libre ejercicio de la religión bajo la RFRA e igual protección. Por el contrario, como sabemos (vid supra, nota $\mathrm{n}^{\circ} 81$ ) un tribunal federal de distrito resolvió a favor de la administración en Sarsour v. Trump, 2017 U.S. Dist. LEXIS 43596 (ED VA, March 24, 2017).

${ }^{86}$ Cfr. Lemon v. Kurtzman, 403 U.S. 602, at 612-13 [Burger, C.J.] (June 28, 1971). 
banc (10 a 3) la prohibición temporal de la EO-2 que el tribunal federal de Maryland había concedido. Ese mismo día el fiscal general ya anunció su intención de recurrir esta decisión a la USSC y el 14 de junio Trump extendió la fecha de entrada en vigor de la EO-2, suspendida por esas órdenes judiciales, al tiempo en el que fueran levantadas las mismas.

Así estaban las cosas cuando el 26 de junio la USSC se pronunció sobre la validez de la EO-2. A fin de levantar parcialmente las prohibiciones que pesaban sobre esta orden presidencial, el Tribunal, en su opinión per curiam, recurrió a una vía intermedia entre los tribunales de apelación o circuitos y el ejecutivo, solución construida sobre el concepto de la buena fe. En relación a la sección 2 (c) sobre la prohibición de entrada en el país de los nacionales de esa serie de seis países, ahora, decía el Supremo, no estarían sujetos a esa prohibición los que pudieran demostrar la existencia de una relación de buena fe con una persona o entidad en Estados Unidos. Tal sería el caso de las relaciones familiares, mientras que para el resto de extranjeros seguiría operando válidamente la medida y no podrían entrar en el país. En el caso de las entidades o personas jurídicas, la relación de buena fe debería ser formal, ordinaria y documentada, sin intención alguna de evadir lo dispuesto en la EO-2 (ejemplos de estas relaciones serían los de un estudiante con la Universidad americana que lo admite, un trabajador que acepta una oferta de trabajo de una empresa norteamericana o un conferenciante invitado a dirigirse a una audiencia americana en Estados Unidos; en cambio, no sería el caso de aquellos con los que entraron en contacto organizaciones no lucrativas norteamericanas de inmigración para luego reclamar esa conexión que les eximiría de la prohibición). Además, ese mismo concepto de buena fe fue aplicado por la USSC en relación a la otra medida controvertida de la EO-2 referida a los casos de refugiados, levantando también aquí de modo parcial la prohibición judicial que sobre esta medida pesaba. En este sentido, dijo la USSC que un individuo o entidad americana que tuviera una relación de buena fe con una persona buscando refugio podría reclamar el daño concreto que provocaría de ser excluida; para los demás casos, la seguridad nacional exigía deferencia a la decisión del gobierno. Aún así, la USSC aplazó la discusión del caso durante la primera sesión del próximo año judicial. El juez Thomas, al que se le unieron los jueces Alito y Gorsuch, ofreció una opinión en parte disidente en la que hubiera preferido paralizar, completamente y sin más, la orden judicial que prohibía la aplicación de la EO-2, sin gustarle ese concepto de «relación de buena fe» cuya clarificación llenaría de controversias los tribunales. 
El 13 de julio el tribunal federal de distrito de Hawaii, en State of Hawaii v. Trump, 2017 U.S. Dist. LEXIS 109034 (D HI, July 13, 2017), denunció la interpretación restrictiva que quería hacer el gobierno de ese concepto de «relación de buena fe» al que había llegado la USSC y sostuvo que esa clase de relación, en el caso de las familias, debía incluir abuelos, nietos, cuñados, tíos, sobrinos y primos de personas en los Estados Unidos. Además, dijo que un refugiado tendría esa relación de buena fe con una entidad estadounidense cuando una agencia hubiera asegurado que proporcionará a esa persona los servicios necesarios de recepción, como era el caso de un programa federal desde 1990, el Lautenberg Program que surgió para refugiados de la antigua Unión Soviética. Pues bien, ese mismo día la administración Trump pidió al Supremo que clarificara la situación y dijera si la lectura que hacía ese tribunal federal de su decisión era o no la correcta. Y fue entonces cuando, el 19 de julio de 2017, la USSC, en Trump v. Hawaii, 2017 U.S. LEXIS 4322 (2017), no quiso suspender la parte de las sentencia de ese tribunal de distrito que permitía la entrada en el país a las personas con esas relaciones familiares como de buena fe. En cambio, sí suspendió temporalmente, mientras el caso estuviera en apelación ante el noveno circuito, la otra parte de la sentencia de Hawaii relativa a los refugiados. De nuevo los jueces Thomas, Alito y Gorsuch hubieran detenido por entero la ejecución de la sentencia recurrida. El 7 de septiembre, el noveno circuito respaldaba la sentencia apelada del tribunal de distrito en los dos capítulos vistos: State of Hawaii v. Trump, 2017 U.S. App. LEXIS 17340 (9th Cir., 2017). Pero el 12 de septiembre la USSC emitió una orden deteniendo la ejecución de lo dispuesto por el noveno circuito en relación a los refugidados. Así el Supremo zanjó la discusión en Trump v. Hawaii, 2017 U.S. LEXIS 4432 (2017), insistiendo en que todos los refugiados de los países incluidos en la prohibición de la orden presidencial cuya conexión con Estados Unidos fuera sólo un seguro de colocación seguirían sujetos a la prohibición de la EO-2, hasta que el Tribunal Supremo se pronunciara sobre el fondo de esta cuestión, la validez de la orden ejecutiva, en el próximo año judicial a partir del mes de octubre de 2017. Mientras tanto, el domingo 24 de septiembre Trump hizo pública una nueva proclamación presidencial en materia migratoria para entrar en vigor el 18 de octubre prohibiendo de forma indefinida la entrada en el país a una serie de extranjeros procedentes de siete naciones, algunas de ellas ahora no musulmanas: Irán, Libia, Siria, Yemen, Chad, Venezuela y Corea del Norte. Esto es lo que seguramente podrá evitar las denuncias sobre su validez constitucional. De la pasada lista de países se ha eliminado ahora a Sudan y se han añadido otros 
como los de Chad, Corea del Norte y Venezuela. Los nacionales de Irak, de Somalia y ciertos colectivos de Venezuela estarán sujetos a restricciones y controles más rigurosos ${ }^{87}$. El caso es que el 3 de octubre de este año 2017 volvía a plantearse la cuestión de la validez constitucional de esta nueva iniciativa de Trump en la materia como una violación del no establecimiento, de la «Immigration and Nationality Act», así como de otras medidas de la Primera y Quinta Enmienda en Iranian Alliances Across Borders v. Trump (D MD, October 3, 2017). A la semana, el 10 de octubre, en Trump v. Int'I Refugee Assistance, et al., 2017 US LEXIS 6265 (2017), la USSC ordenó la anulación de la sentencia recurrida del cuarto circuito y el envío del caso a ese tribunal con instrucciones para considerarlo no justiciable (moot case) ante la nueva iniciativa presidencial del 24 de septiembre que evitaba ya considerarlo un caso o controversia. La juez Sotomayor mostró su desacuerdo acerca de la orden dada que anulaba la decisión recurrida. Y el 17 de octubre un tribunal federal de Hawaii volvió a paralizar, con una nueva TRO, la tercera orden presidencial, la del 24 de septiembre, en State of Hawaii v. Trump, 2017 US Dist. LEXIS 171242 (D. HI, Oct. 17, 2017).

\section{CONTROVERSIAS INTERNAS}

Pfeil v. St. Mattherws Evangelical Lutheran Church, 137 S.Ct. 493 (2016). El 28 de noviembre de 2016 la USSC rechazó la apelación de una controversia del Supremo de Minnesota en el que, por la doctrina de la abstención eclesiástica, este Tribunal no quiso conocer la acción de difamación planteada contra una iglesia y sus pastores por las declaraciones realizadas durante un proceso disciplinar que buscaba la excomunión de los demandantes, cuando esas declaraciones sólo se habían vertido a los miembros de la iglesia y a los que participaban en esa clase de proceso disciplinario ${ }^{88}$.

Tung v. China Buddhist Association, 137 S.Ct. 628 (2017). En esta ocasión, la USSC, el 9 de enero de 2017, rechazó el recurso presentado ante una decisión de un tribunal de New York que había rechazado ordenar a un templo budista sostener una reunión en un caso de elecciones internas cuando los miem-

\footnotetext{
${ }^{87}$ Cfr. Presidencial Proclamation Enhancing Vetting Capabilities and Processes for Detecting Attempted Entry Into the United States by Terrorists or Other Public-Safety Threats, September 24, en https://www.whitehouse.gov/the-press-office/2017/09/24/enhancing-vetting-capabilities-andprocesses-detecting-attempted-entry.

88 Cfr. Pfeil v. St. Matthews Evangelical Lutheran Church, 877 N.W.2d 528 (Minn. April 6, 2016).
} 
bros estaban excomulgados. El tribunal entendió que el caso era de naturaleza religiosa y no secular, no siendo posible la aplicación a él de principios neutrales de derecho ${ }^{89}$.

Board of Pensions of the Evangelical Lutheran Church v. Bacon, 137 S.Ct. 1213 (2017). El 27 de febrero de 2017 la USSC no vio la oportunidad de entrar en un caso en el que un tribunal estatal de Minnesota había sostenido que la doctrina de la abstención eclesiástica de la Primera Enmienda no impedía a la jurisdicción civil conocer el modo como habían sido gestionados los planes de jubilación de una iglesia aplicando para ello principios neutrales de derecho a fin de poder resolver el litigio entre la institución religiosa y sus feligreses. Los demandantes estaban reclamando incumpliento de deber y fraude ${ }^{90}$.

Chabad-Lubavitch of Michigan v. Schuchman, 136 S.Ct. 2449 (2016). En este caso, el Supremo de Michigan había anulado la sentencia recurrida en una controversia sobre propiedad entre el Chabad-Lubavitch estatal de Michigan y la organización local ${ }^{91}$. En juego estaba la prescripción o no de la deuda, sin que el tribunal estatal de apelación se hubiera inmiscuido en asuntos internos de carácter religioso. La USSC no admitió el recurso de apelación contra esa sentencia el 23 de mayo de 2016.

Nolen v. Diocese of Birmingham in Alabama, 2017 U.S. Dist. LEXIS 141496 (ND AL, Sept. 1, 2017). Este tribunal federal de distrito de Alabama invocó la doctrina de la excepción ministerial para rechazar la denuncia planteada por la directora de una escuela elemental católica que había sido despedida de su puesto, según ella por intentar frenar las prácticas discriminatorias de la escuela y sus trabajadores contra las familias y alumnos hispanos. La Diócesis negaba la acusación de discriminación racial y ofrecía una versión muy distinta de los hechos en la que la directora había sido acusada por malversación de fondos.

Church of God in Christ, Inc. v. L.M. Haley Ministries, Inc., 2017 Tenn. LEXIS 565 (Tenn., September 21, 2017). En este caso de disputa acerca de la

${ }^{89}$ Cfr. Matter of Ming Tung v. China Buddhist Assn., 26 N.Y.3d 1152 (NY Ct App., February 18, 2016).

90 Cfr. Bacon v. Bd. of Pensions of the Evangelical Lutheran Church in Am., 2016 Minn. App. Unpub. LEXIS 729 (Minn. Ct. App., July 25, 2016).

${ }^{91}$ Cfr. Chabad-Lubavitch of Mich. v. Schuchman, 497 Mich. 1021 (Mich., May 20, 2015). 
propiedad de una iglesia, el Tribunal Supremo de Tennessee aplicó una versión híbrida de la doctrina de los principios neutrales de derecho a emplear en estos casos y dijo que, para resolver esa clase de controversias, los tribunales estatales podrían tomar en consideración una serie de documentos relevantes como: las escrituras y cualquier otro documento de traspaso, así como cualquier disposición relativa a la propiedad que pudiera incluirse en las constituciones eclesiásticas locales o jerárquicas o en sus documentos de gobierno. Es más, los tribunales civiles podrían hacer valer el fideicomiso a favor de la iglesia jerárquica incluso aunque ello únicamente figurara en la constitución o en los documentos de gobierno de la organización religiosa jerárquica.

Rymer v. Lemaster, 2017 US Dist. LEXIS 165532 (MD TN, October 4, 2017). En este caso, la juez Roberts rechazó, en virtud de la doctrina de la «ecclesiastical abstention», una demanda planteada por un estudiante de un College de la University of Tennessee contra un pastor baptista, Roger Oldham, que le convirtió al cristianismo. Para ello parece se había servido de cierta información recibida durante las sesiones de consejería espiritual así como de una atractiva estudiante. El alumno Lincoln Rymer pedía más de 15 millones de dólares por daños físicos, psicológicos y económicos sufridos.

\section{Privilegio de Confidencialidad: Sacerdote-Penitente}

El 2 de noviembre de 2015 fueron publicados en el National Catbolic Reporter los resultados de una investigación sobre el alcance económico de las denuncias de abusos sexuales en el caso de la Iglesia católica ${ }^{92}$. Desde 1950 la Iglesia se ha gastado, estimando a la baja el coste total, cerca de 4 billones de dólares entre juicios y acuerdos extrajudiciales, terapias para las víctimas, atención a los delincuentes, honorarios de abogados, además de diversos esfuerzos para la protección de los menores y otros gastos relacionados con esta cuestión. A este dinero habría que añadir la suma de contribuciones que las caridades católicas han dejado de recibir por los cerca de 3.000 escándalos entre 1980 y 2010, y que ciertos estudios elevan a billones de dólares. Un año después de la publicación de este informe, los esfuerzos de las diócesis para gestionar ade-

92 Cfr. J. RUHL - D. RUHL, NCR research: Costs of sex abuse crisis to US church underestimated, November 2, 2015, en https://www.ncronline.org/news/accountability/ncr-research-costs-sex-abuse-crisis-us-church-underestimated. 
cuadamente este triste asunto seguían materializándose en iniciativas como la de la diócesis de New York creando un fondo de compensación para las víctimas de abusos sexuales, fondo gestionado por el abogado Kenneth Feinberg que había admnistrado el fondo federal de compensación para las víctimas del 11 de septiembre. Para todos los que fueron compensados, los informes de abusos y la respuesta de la Iglesia en esos casos seguirían siendo privados a menos que las víctimas quisieran hacerlos públicos. Las reclamaciones pendientes podrían presentarse hasta el 31 de enero de 2017 y desde el 1 de febrero las víctimas que aún no hubieran presentado sus reclamaciones podrán hacerlo.

Una de las primeras medidas que en Estados Unidos se abordaron para frenar los abusos sexuales, dentro y fuera de la Iglesia, siendo la familia el principal lugar en el que esos casos suceden, fue la obligación de informar inmediatamente a la policía, tan pronto como los hechos de abuso sexual a menores fueran conocidos. Ahora bien, los sacerdotes católicos tienen un ámbito privilegiado de acceso a esa clase de información pero protegido por el sigilo sacramental, algo que va más allá de la confidencialidad y que coloca al sacerdote en la necesidad de guardar absoluto silencio sobre lo oído en confesión sin poder identificar tan grave crimen con su verdugo. Pues bien, los Estados sí han querido proteger esta relación singular a través de una exención a la obligación de informar, una exención que opera en el área de la confesión y que es conocida como privilegio sacerdote-penitente. Sin embargo, van surgiendo voces que no aceptan este marco de inmunidad, algunos se han enfrentado a él tan abiertamente como el reciente informe de una comisión australiana que pedía la denuncia a las autoridades de todo lo recibido en confesión sobre abuso sexual a menores ${ }^{93}$. En los Estados Unidos también ha habido casos en los que se ha intentado, en estos dos últimos años judiciales, limitar esa esfera de protección aunque sin mucho éxito. La controversia más conocida en este asunto tuvo lugar en Louisiana cuando una joven de unos 14 años dijo en el 2008 a un sacerdote de la diócesis de Baton Rouge, dentro del sacramento de la confesión, que había sido abusada por un adulto de 64 años de la comunidad parroquial, más tarde fallecido. El sacerdote no informó de esa situación a las autoridades porque no podía hacerlo, sino quería exponerse a una excomunión latae sententiae. Cuando surgió la controversia, los padres de la menor decidieron actuar además de contra el cul-

93 Cfr. Royal Commission into Institutional Responses to Child Sexual Abuse, Criminal Fustice, August 14, 2017, pp. 52-53, en https://www.childabuseroyalcommission.gov.au/mediacentre/media-releases/2017-08/report-on-criminal-justice-released. 
pable, contra este sacerdote por no haber informado de ello y contra la diócesis por su responsabilidad vicaria. La ley estatal obligaba denunciar estos casos de abuso, salvo en caso de comunicación confidencial al clero. Tratándose además del sacramento católico de la confesión existía además para el sacerdote la exigencia de sigilo. Un tribunal estatal de apelación corrigió el fallo recurrido y, por ser una confesión sacramental, desestimó la demanda contra el sacerdote. El Supremo de Lousiana anuló la decisión apelada y reenvió el caso al tribunal de distrito para dilucidar si había o no confesión, entrando así en el alcance de esa comunicación. El 20 de enero de 2015 la USSC rechazó la apelación presentada ${ }^{94}$. Hasta aquí lo que ya sabemos por crónicas pasadas. El caso es que en febrero de 2016 un juez estatal de un tribunal de distrito anuló la cláusula legal («LA Children's Code» Sec. 609[A][1]) que exigía al clero la denuncia de ese tipo de casos. Basándose en la ley estatal de libertad religiosa, «Preservation of Religious Freedom Act», el tribunal sostuvo que si podía decirse que el Estado tenía un poderoso interés estatal en la protección de los menores, sin embargo esa obligación de informar no era la medida menos restrictiva para lograr ese interés. Por otra parte, se permitía que la demandante testificara sobre lo dicho en confesión, algo que fue confirmado posteriormente en Mayeux v. Charlet, 2016 La. App. LEXIS 1464 (La. App., July 29, 2016), aunque con el voto en contra de un juez de un tribunal estatal de apelación, pues eso vulneraría el libre ejercicio religioso del sacerdote y la separación debida entre la Iglesia y el Estado. Al mismo tiempo, el Supremo de Louisiana anuló la decisión del tribunal de distrito que había declarado nula la sección de la ley que exigía el informe de esa clase de casos. El de distrito no tenía que haberlo hecho cuando no era necesario, pues el sacerdote no tenía por qué informar de las noticias recibidas en confesión. Y es que, en Mayeux v. Charlet, 203 So. 3d 1030 (LA, October 28, 2016), este Tribunal dijo que un sacerdote durante la confesión no era un «informador necesario» en el sentido de la sección 603 del «Louisiana Child Code», por lo

${ }^{94}$ Cfr. Parents of Minor Child v. Charlet and the Roman Catholic Church of the Diocese of Baton Rouge, 139 So. 3d 519 (La., May 23, 2014); Parents of Minor Child v. Charlet, 135 So. 3 d 1177 (La., April 4, 2014). Parents of Minor Child v. Charlet, 135 So. 3d 724 (La. App. 1 Cir., 2013). La diócesis de Baton Rouge reaccionó inmediatamente con un comunicado en el que se oponía al fallo del Supremo de Louisiana, por ser contrario a la garantía constitucional de no establecimiento. No podía ordenar este tribunal al de distrito lo que ninguno puede hacer: determinar lo que constituye el sacramento de la reconciliación en la iglesia católica, cfr. http://www.diobr.org/chanceryannouncements/258-july-7-2014-official-statement-from-diocese-re-court-cases. La USSC no quiso entrar en el caso en Roman Catholic Church of the Diocese of Baton Rouge v. Mayeux, 135 S.Ct. 1154 (writ of certiorari denied, January 20, 2015). 
que no estaba obligado, bajo la sección 609 , a reportar lo recibido en confesión, dado que el 603(15)(c) específicamente eximía la comunicación confidencial al clero bajo el priviliegio del art. 511 del «Louisiana Code of Evidence». Los sacerdotes católicos podrían seguir protegidos en el ejercicio de su ministerio dentro del sacramento de la confesión.

Lamentablemente los medios de comunicación y algunos feligreses no siempre se han movido en esta desgraciada cuestión buscando la verdad. En el modo de proceder de la Iglesia en relación a sus sacerdotes acusados (inmediatamente es apartado del ejercicio de sus funciones, desde luego y siempre con menores, por lo que si alguien no quisiera en su parroquia a un sacerdote, ésta ha sido de hecho una buena vía para hacerle salir de ella) y por las cuantiosas indemnizaciones en juego, ha habido casos de falsas acusaciones contra ellos. Uno de ellos tuvo que ver con un sacerdote de origen chino en la diócesis de St Louis (Missouri) que tuvo que defenderse de una falsa acusación de abuso infantil planteada con el único fin de obtener dinero. Father Joseph Jiang inició entonces una acción judicial contra los padres del menor que le habían acusado falsa e injustamente, contra los policías que le habían perseguido a causa de su religión y raza, contra la asociación de víctimas de abusos ( «Survivors Network of Those Abused by Priests», SNAP) por la difamación sufrida en la campaña dirigida contra él en la prensa. Si todos ellos hubieran hecho bien su trabajo se hubieran dado cuenta que el menor, mental y emocionalmente perturbado, ya había hecho en el pasado otras reclamaciones de abuso sexual, que los padres tenían también una buena historia de infundadas alegaciones contra la Iglesia católica con el fin de conseguir dinero y que había una serie de circunstancias y evidencias claras a favor de la inocencia del sacerdote. Pues bien, un tribunal federal de distrito de Missouri resolvió, en fiang v. Porter (ED 2015 y 2016) ${ }^{95}$, a favor de las peticiones de igual protección, proceso justo y angustia emocional del sacerdote contra los dos agentes de policía, rechazando la responsabilidad vicaria de la ciudad de St. Louis y permitiendo que procediera en su demanda de difamación contra la SNAP. Por último, otro supuesto que se planteó en Louisiana tuvo que ver de nuevo directamente con el sigilio sacramental y su alcance. El caso surgió cuando la demandante tuvo conocimiento de la declaración de un sacerdote que se refería a ella como alguien que se acercaba al con-

${ }^{95}$ Cfr. Fiang v. Porter, 156 F. Supp. 3d 996 (ED Mo., December 28, 2015); Fiang v. Porter, 2015 U.S. Dist. LEXIS 172215 (ED Mo., December 28, 2015); y fiang v. Porter, 2016 U.S. Dist. LEXIS 5244 (ED Mo., January 15, 2016). 
fesionario sin motivos claros. Esto provocó la denuncia de lo que ella suponía quiebra del secreto y por ello planteó una demanda que no prosperó en Sonnier v. Roman Catholic Diocese of Lafayette, 2017 U.S. Dist. LEXIS 27235 (WD LA, January 18, 2017) y 2017 U.S. Dist. LEXIS 26498 (WD LA, February 23, 2017). El tribunal no quiso entrar en esta cuestión para evitar conocer de asuntos eclesiásticos internos, como sería la definición de la ruptura del sigilo sacramental, inmiscuyéndose en cuestiones internas de la Iglesia católica.

Fuera del caso de los sacerdotes católicos, el privilegio de confidencialidad de los clérigos o pastores, en su relación con los fieles, planteó también alguna que otra controversia en estos años. Así, por ejemplo, en State of Delaware v. Laurel Delaware Congregation of Jehovah's Witnesses, 2016 Del. Super. LEXIS 49 (DE Superior Court, January 26, 2016), dentro de un caso de abuso infantil entre un menor de 14 años y una mujer miembro de esa congregación que no había sido reportado debidamente por sus responsables que buscaban el amparo de la cláusula estatal que eximía de la obligación de informar a la relación cualificada entre abogado y cliente, así como entre sacerdote y penitente dentro de una confesión sacramental (sección 909 del Delaware Code, Title 16, Chapter 9), este tribunal estatal sostuvo que, de entenderla estrictamente, esa cláusula legal sería inconstitucional porque crearía una excepción únicamente para ciertas denominaciones religiosas. En el caso, las conversaciones, más que con un propósito penitencial, buscaban consejo o asistencia espiritual. En otro caso que afectó a los testigos de Jehová, un tribunal estatal de apelación de Ohio, en McFarland v. West Congregation of fehovah's Witnesses, Lorain, Obio, Inc., 60 N.E.3d 39 (OH App., Aug. 22, 2016), negó que la entrega de documentos solicitados a los que la demandada se resistía bajo ese privilegio de relación clero-penitente (sólo 4 de 19 podrían considerarse dentro de ese privilegio), en otro caso de abuso de menores, expusiera las creencias relativas al arrepentimiento, redención y misericordia, así como los procesos internos de disciplina de la iglesia, a un examen secular contrario a las garantías religiosas de la Primera Enmienda.

\section{Otros Casos}

Center for Competitive Politics v. Harris, 136 S.Ct. 480 (2015). El 9 de noviembre de 2015 la USSC rechazó la apelación que le llegó del noveno circuito en un caso en el que este tribunal había mantenido la exigencia que imponía California para lograr contribuciones deducibles de impuestos en ese 
Estado. La ley exigía a las organizaciones benéficas o a otras sin ánimo de lucro (como las religiosas) la obligación de presentar un informe anual no público que incluyera un formulario del IRS (la agencia tributaria federal «Internal Revenue Service») con los nombres y contribuciones de donantes importantes. Una de esas organizaciones había denunciado la medida como contraria a las grantías religiosas de la Primera Enmienda pero el tribunal no creyó probada ninguna amenaza u hostigamiento por esa divulgación ${ }^{96}$.

James v. City of Boise, Idaho, 136 S.Ct. 685 (2016). El 25 de enero de 2016 la USSC en una opinión per curiam anuló una sentencia recurrida del Tribunal Supremo de Idaho en relación a una cuestión sobre el pago de honorarios a los abogados en casos frívolos o sin fundamentación de derechos civiles en el nivel estatal. La interpretación que hacía de esta cuestión la USSC no la creyó el de Idaho vinculante en la esfera de los Estados ${ }^{97}$. La USSC aquí, en cambio, sostuvo que una vez que ella interpreta la ley, esa lectura es vinculante y el derecho estatal debe ajustarse a ella.

Sunrise Children's Services v. Glisson, 136 S.Ct. 2449 (2016). El 23 de mayo de 2016 la USSC rechazó el recurso de apelación que se le había presentado desde el sexto circuito en un litigio sobre ayudas a entidades religiosas en el que estaba en juego la legitimación activa del denunciante. Se trataba de un viejo caso en el que se había denunciado, como contraria al no establecimiento religioso, la ayuda estatal que Kentucky ofrecía a una organización baptista («Sunrise Children's Services») para la atención de niños abusados o abandonados en sus instalaciones ${ }^{98}$.

En United States v. Christie, 825 F.3d 1048 (9th Cir., June 14, 2016), el noveno circuito mantuvo las condenas por fabricación y distribución de ma-

${ }^{96}$ Cfr. Center for Competitive Politics v. Harris, 784 F.3d 1307 (9th Cir. Cal., May 1, 2015).

97 Cfr. James v. City of Boise, 158 Idaho 713 (Idaho, May 21, 2015).

98 Cfr. Pedreira v. Sunrise Children's Services, Inc., 802 F.3d 865 (6th Cir., October 6, 2015). El caso era el siguiente: Flast v. Cohen, 392 US 83 (1968) había reconocido legitimación activa (standing) a los contribuyentes para denunciar supuestos contrarios a las garantías de no establecimiento siempre que mantuvieran esos contribuyentes una relación o nexo con la legislación o media impugnada. El sexto circuito había debilitado ese nexo en este caso a diferencia de las decisiones en la materia de la USSC que, por otra parte, nunca había dicho que Flast fuera de aplicación a los contribuyentes estatales, siendo así que los circuitos estaban divididos. Por eso se procedió al recurso de apelación ante la USSC, a fin de resolver dos cuestiones: (1) si Flast debiera o no ser anulada; y (2) si Flast debiera extenderse a los Estados. No obtuvieron respuesta. 
rihuana que pesaban sobre el fundador (también sobre su esposa) de una organización religiosa llamada «Hawaii Cannabis Ministry» establecida en el año 2000. Ellos creían que había sido vulnerado su libre ejercicio religioso bajo la RFRA pero el tribunal dijo que el poderoso interés estatal en la materia había llevado a aplicar además la medida menos restrictiva posible para lograrlo.

Oklevueha Native American Church of Hawaii v. Lynch, 137 S.Ct. 510 (2016). El 28 de noviembre de 2016 la USSC rechazó el recurso de apelación presentado contra una sentencia del noveno circuito que había fallado, a pesar de la defensa invocada de la RFRA, contra el rechazo de una exención a las leyes federales que prohibían la tenencia y distribución de cannabis solicitada por esa iglesia nativa americana y su fundador. Y es que no se había podido probar en el caso que la prohibición de cannabis les hubiera obligado a elegir entre la obediencia a su religión y la sanción criminal ${ }^{99}$.

En New Doe Child \#1 v. Congress of the United States, 2016 U.S. Dist. LEXIS 165156 (ND OH, November 30, 2016), un tribunal federal de distrito de Ohio rechazó los argumentos de libre ejercicio bajo la RFRA, de libertad de expresión y de igual protección por el empleo del lema federal «In God We Trust» de las monedas. El grupo de demandantes (ateos y sus hijos, así como personas creyentes que veían el uso de Dios en la moneda como algo pecaminoso) no había logrado demostrar que su libre ejercicio religioso hubiera sido sustancialmente limitado.

En United States v. Barnes, 677 Fed. Appx. 271 (6th Cir., January 26, 2017), el sexto circuito falló en contra de la pretensión del miembro de aquella iglesia nativo americana ya vista («Oklevueha Native American Church»), acusado de cultivar grandes cantidades de marihuana. En defensa propia alegó que la Primera Enmienda y la RFRA le permitían el cultivo de ese material para donarlo a la iglesia. El tribunal no vio que hubiera sido vulnerado sustancialmente el libre ejercicio religioso de Barnes: ni su religión le obligaba a esa clase de cultivo, por lo que se trataba más de bien de una opción personal, ni la marihuana tenía para esa religión carácter sacramental (la única sustancia sagrada era el peyote) sino más bien era una medicina.

${ }^{99}$ Cfr. Oklevueba Native Am. Church of Haw., Inc. v. Lynch, 828 F.3d 1012 (9th Cir., April 6, 2016). 
En Mendoza v. Nordstrom, Inc., 2 Cal. 5th 1074 (CA, May 8, 2017), el Supremo de California respondió a unas cuestiones que le hizo llegar el noveno circuito a fin de clarificar el sentido del «día de descanso» al que se refería la ley estatal de trabajo. Ese día suponía una jornada de descanso a la semana de libre elección del trabajador o uno al menos cada siete días, pudiendo además el empleado, debidamente informado de su derecho al descanso, renunciar a él.

Armstrong v. Kilmartin, 2017 U.S. Dist. LEXIS 75169 (D RI, May 17, 2017). Un tribunal federal de distrito de Rhode Island no quiso detener la acusación contra el uso de cannabis en los rituales religiosos de una iglesia, «Healing Church», por su líder religiosa y los ministros de esa iglesia, a pesar de la defensa que hacían de su libre ejercicio religioso y de discriminación contra ellos por su religión.

Standing Rock Sioux Tribe v. U.S. Army Corps of Engineers, 205 F. Supp. 3d 4 (D DC Sept. 9, 2016). Un tribunal federal de distrito de DC rechazó paralizar la construcción de un oleoducto cerca de una reserva india que afectaba a tierras sagradas de los Sioux. Sin embargo, los Departamentos de Justicia, Ejército e Interior decidideron no conceder el permiso hasta ver si lesionaba o no la «National Historic Preservation Act» (NHPA), además de otras leyes federales. En diciembre, el Ejército anunció que no iba a conceder la autorización para atravesar el lago Oahe en North Dakota, pero Trump, al llegar a la Casa Blanca, emitió un Memorandum el 24 de enero urgiendo al Departamento del Ejército a proceder. Pues bien, en marzo de 2017, un tribunal federal de DC, en Standing Rock Sioux Tribe v. U.S. Army Corps of Engineers, 239 F. Supp. 3d 77 (D DC, March 7, 2017), rechazó el argumento de libertad religiosa bajo la RFRA presentado por la tribu Sioux: la aprobación del proyecto no impedía sus creencias religiosas ni les presionaba en orden a elegir entre el ejercicio religioso y la obtención de beneficios gubernamentales. Mejor suerte tuvo la reclamación relativa al impacto medioambiental del proyecto pues el mismo tribunal, ahora en Standing Rock Sioux Tribe v. U.S. Army Corps of Engineers, 2017 U.S. Dist. LEXIS 91297 (D DC, June 14, 2017), pedía se tuviera en consideración el impacto que un derrame de petróleo podría tener sobre los derechos de pesca o de caza. A decir verdad, éste no fue el único caso en el que la propiedad de unas tierras se vio afectada por el proyecto de un oleoducto. En Transcontinental Gas Pipeline Co., LLC v. Permanent Easement for 2.14 Acres, 2017 U.S. Dist. LEXIS 134851 (ED PA, Aug. 23, 2017), un tribu- 
nal federal de distrito en Pennsylvania falló en contra de la pretensión de una orden religiosa femenina («Adorers of the Blood of Christ») sobre su tierra. Las hermanas recurrían en su defensa al ejercicio de sus creencias religiosas, unas creencias que las obligaban a proteger y defender su tierra a fin de preservar la santidad de la tierra de Dios. Para el tribunal, las religiosas no habían logrado demostrar cómo permitir el paso del oleoducto por su tierra podría afectar al modo de ejercer su fe y difundir su mensaje.

Animal Protection and Rescue League v. City of Los Angeles, Case 8:17-cv01581-JLS-JDE (CD CA, filed September 12, 2017). Un grupo de animalistas acaban de presentar esta denuncia ante un tribunal federal de distrito de California buscando detener la práctica de agitar los pollos sobre la cabeza de las personas y después entregarlos a los pobres como un acto de caridad dentro del ritual judío pre-Yon Kippur conocido como «Kapparot». Que muchos de esos animales terminen abandonados en las calles fue visto como un trato cruel por esas sociedades animalistas que han denunciado en los tribunales esa práctica como contraria al no establecimiento religioso, desde el momento en el que ciudades como ésta de Los Angeles y sus departamentos de policía parecían respaldar esa práctica ilegal para ellos.

Gaylor v. Mnuchin, 2017 US Dist. LEXIS 165957 (WD WI, October 6, 2017). Este tribunal federal de Wisconsin, en este caso planteado por los presidentes de la asociación «Freedom From Religion Foundation», sostuvo que la medida prevista en el «Internal Revenue Code» (Sec. 107, 2) violaba la garantía constitucional de no establecimiento religioso desde el momento en el que permitía al clero excluir de sus ingresos la cantidad recibida y destinada a cubrir la renta de su casa o alojamiento. Eso parecía un trato especial hacia esa categoría de trabajadores que no obedecía a razones seculares. A pesar de ello, la juez Crabb emplazó a las partes a que le hicieran llegar escritos suplementarios.

Harris v. City of Clearlake, 2017 US Dist. LEXIS 167430 (ND CA, October 10, 2017). En este caso, un tribunal federal de California respaldó la regulación municipal sobre cultivo médico de marihuana que lo restringía, entre otras condiciones, a sólo seis plantas. Para la juez Gonzalez Rogers, esa normativa local era neutral y de general aplicación, sin que el ministro y fundador de una iglesia («Church of the Greater Faith \& Redemption»), que cultivaba esas sustancias por razones sacramentales, hubiera podido demostrar 
que la prohibición de cultivar más de seis plantas de marihuana le fueran insuficientes para satisfacer sus necesidades religiosas o que no pudiera hacerse con más marihuana de otro modo.

\section{NueVOS TIEMPOS PARA LA LIBERTAD PRIMERA CON TRUMP Y SIN SCALIA}

El juez asociado del Supremo Antonin Scalia falleció repentinamente el 13 de febrero de 2016 a los 79 años, dejándonos como herencia un elenco de importantes decisiones en las que se fue definiendo su doctrina sobre la primera de las libertades ${ }^{100}$. Como hemos dicho en algún otro lugar, Scalia fue un textualista, originalista y, de algún modo, también partícipe de un cierto positivismo legal, mucho menos dado a recurrir al derecho natural que su colega en la USSC el juez Clarence Thomas ${ }^{101}$. El juicio que, hace años, hiciéramos de su comprensión de la libertad religiosa se fue manteniendo en el tiempo: «El neutrality standard de Scalia -dijimos entonces- ha supuesto, en el free exercise, el abandono del Sherbert test en Smith y, en la interpretación de la establishment clause, la adaptación de la religión mayoritaria a través de las dos notas presentes en la definición del no-establecimiento: no preferencia y no coacción» ${ }^{102}$. En síntesis, la comprensión de Scalia de la libertad religiosa sería algo así como una débil lec-

${ }^{100}$ Cfr. Edwards v. Aguillard (1987) (opinión disidente); Employment Division v. Smith (1990) (opinión mayoritaria); Lee v. Weisman (1992) (opinión disidente); Church of the Lukumi Babalu Aye, Inc. v. City of Hialeab (1993) (opinión concurrente); Lamb's Chapel v. Center Moriches Union Free School District (1993) (opinión concurrente); Board of Education of Kiryas Foel Village School District v. Grumet (1994) (opinión disidente); Capitol Square Review and Advisory Board v. Pinette (1995) (opinión del tribunal); City of Boerne v. Flores (1997) (opinión concurrente); Watchtower Bible and Tract Society of New York, Inc. v. Village of Stratton (2002) (opinión concurrente); Locke v. Davey (2004) (opinión disidente); Van Orden v. Perry (2005) (opinión concurrente); McCreary County v. ACLU (2005) (opinión disidente); Elmbrook School District v. Doe (2014) (disintiendo del rechazo del recurso); EEOC v. Abercrombie \& Fitch Stores, Inc. (2015) (opinión mayoritaria); Webster v. Reproductive Health Services (1989) (concurriendo en parte); Ohio v. Akron Center for Reproductive Health (1990) (opinión concurrente); Planned Parenthood of Southeastern Pennsylvania v. Casey (1992) (concurriendo y disintiendo); Shenck v. Pro-Choice Network of Western New York (1997) (concurriendo y disintiendo); Stenberg v. Carhart (2000) (opinión disidente); Lawrence v. Texas (2003) (opinión disidente); y Obergefell v. Hodges (2015) (opinión disidente). Por otra parte, no fue la suya la única pérdida en lamentar durante el tiempo que nos ocupa en esta crónica. El 17 de abril de 2017 también nos dejó el juez John T. Noonan Jr. del noveno circuito a la edad de 90 años. Entre sus libros destacan: The Lustre of Our Country: The American Experience of Religious Freedom (1998) o Contraception: A History of Its Treatment by the Catholic Theologians and Canonists (1966).

101 Cfr. J. I. Rubio Lopez, La primera de las libertades..., cit., 226-235.

102 Cfr. ibid., 235. 
tura del free exercise y una también débil comprensión de la garantía del no establecimiento. Pues bien, el 16 de marzo de ese año el presidente Obama hacía público el nombre del elegido para sucederle: Merrick Garland, juez del circuito para el Distrito de Columbia durante 19 años y como Chief Judge del mismo desde el 2013, aunque con poco escrito sobre libertad religiosa o separación Iglesia y Estado. El caso es que, tras las elecciones de noviembre y la llegada a la Casa Blanca de Donald Trump, no prosperó esa nominación y se dejó morir en el Senado. Fue entonces cuando Trump eligió en su lugar, el 31 de enero de 2017, al juez federal del décimo circuito Neil M. Gorsuch. Contaba entonces con 49 años. Nacido en Denver, Colorado, el 29 de agosto de 1967 y educado en instituciones católicas, tras su paso por Columbia, Harvard y Oxford, donde conoció y estudió bajo el magisterio de John Finnis, Gorsuch llegó al décimo circuito de la mano de George W. Bush el 8 de agosto de 2006. Se ha dicho de su filosofía judicial que es textualista y originalista en la interpretación de la Constitución, así como un defensor de la jurisprudencia de derecho natural. Por lo que a nosotros nos afecta singularmente aquí parece partidario de una lectura amplia, a diferencia en este punto de Scalia ${ }^{103}$, de la cláusula religiosa de free exercise, a juzgar por el legado que nos deja su paso por el décimo circuito: opinión concurrente en Hobby Lobby v. Sebelius, 723 F.3d 1114 (2013); voto disidente en Pleasent Grove City v. Summum, 499 F.3d 1170 (2007), sumándose al entonces juez Michael W. McConnell; también disidente en Green v. Haskell County Board of Commissioners, 574 F.3d 1235 (2009); con la opiníon unánime en Abdulhaseeb v. Calbone, 600 F.3d 1301 (2010); en contra de la mayoría también en American Atheists, Inc. v. Davenport, 637 F.3d 1095 (2010); redactando la opinión unánime en United States v. Quaintance, 608 F.3d 717 (2010); uniéndose a la opinión del tribunal en Williams v. Sibbett, 442 Fed. Appx. 385 (2011); escribiendo las opiniones unánimes del tribunal en Yellowbear v. Lampert, 741 F.3d 48 (2014) y en Ali v. Wingert, 569 Fed. Appx. 562 (2014); o de nuevo en contra de la mayoría del tribunal tanto en Little Sisters of the Poor Home for the Aged v. Burwell, 799 F.3d 1315 (2015) como, en uno de sus últimos casos, Planned Parenthood Association of Utab v. Herbert, 839 F.3d 1301 (2016). A estas opiniones en el foro habría que añadir un libro publicado en el 2006 tras sus estudios en Oxford: The Future of Assisted Suicide and Euthanasia. Estos precedentes, con los escasos datos durante los años que nos ocupan en esta crónica (Pavan o Trinity Lutheran), nos

${ }^{103}$ Cfr. N. GoRsuch, Of Lions and Bears, Fudges and Legislators, and the Legacy of Justice Scalia, 66 Case W. Res. L. Rev. 905 (2015-2016). 
acercan, en una primerísima aproximación que habrá que ir contrastando con el tiempo, a una lectura fuerte del free exercise y una débil comprensión del no establecimiento. Nos parece que su interpretación de la libertad religiosa se situaría en lo que tantas veces hemos venido definiendo como lectura positiva de la libertad religiosa, desde una lectura creyente de las cláusulas.

Aun siendo pronto para aventurar el futuro de la libertad religiosa con el juez Gorsuch en el Supremo y el presidente Trump en la Casa Blanca, lo cierto es que allí se ha vuelto a rezar y Trump no ha dejado de invocar a Dios en su deseo de hacer de nuevo grande a America. El creyente judeocristiano no es mirado con recelo o sospecha por la administración y diríase que el péndulo se quiere acercar a la idea de un proyecto personal de libertad, tras años de fuerte insistencia en la igualdad. Los liberales no han renunciado, ni lo harán, a sus cotas conquistadas, pero los conservadores perciben ahora un mayor apoyo a sus reivindicaciones en la recién estrenada administración. $Y$ las vías, intencionalmente cerradas al discurso religioso por los liberales, se van abriendo en las dos direcciones. Por otra parte y en un movimiento sin muchos precedentes en la diplomacia vaticana, el Papa Francisco censuró abiertamente durante la campaña presidencial ciertas propuestas o iniciativas del candidato Trump como la construcción del famoso muro en la frontera de Mexico. Para el Papa levantar muros no era cristiano. Más tarde, con Trump ya en la Casa Blanca, el Santo Padre ha mantenido esa actitud crítica sobre otras medidas, la última de ellas el 11 de septiembre a la vuelta de su viaje a Colombia cuando, aludiendo irónicamente a la condición pro-life del presidente, censuró su iniciativa de cancelar el programa sobre ayudas a niños y jóvenes inmigrantes ilegales que habían entrado en el país como menores («Deferred Action for Childhood Arrivals», DACA) y que había creado la administración Obama en junio de 2012. Para entonces, la revista de los jesuitas La Civilta Cattolica había publicado un artículo en el que sus autores denunciaban una especie de «ecumenismo del odio» fruto de una mala alianza entre el fundamentalismo evangélico y el catolicismo integrista ${ }^{104}$. Mientras tanto, todas estas críticas (internas y externas) a

${ }^{104}$ Cfr. A. Spadaro - M. Figueroa, Fondamentalismo Evangelicale e Integralismo Cattolico. Un sorprendete ecumenismo, 4010 La Civiltà Cattolica 105-113 (2017), en http://www.laciviltacattolica.it/articolo/fondamentalismo-evangelicale-e-integralismo-cattolico/. Este artículo, al que se refería la edición italiana del Osservatore Romano del 14 de julio de 2017 ( ${ }^{\circ}$ 160) en su página 6, fue escrito entre el jesuita Spadaro, director de la revista y muy cercano al Papa Francisco, y el director de la publicación argentina del Osservatore Romano, el protestante Figueroa, amigo personal del Papa, no fue muy bien recibido en Estados Unidos. El arzobispo de Filadelfia Char- 
Trump no parecen afectarle demasiado y continúa con su agenda políticamente incorrecta. Lo que ya podemos decir de estos dos últimos años judiciales (2015-2017) en materia de libertad religiosa es que las controversias se han ido situando entorno a: diversas consecuencias de la legalización del matrimonio entre personas del mismo sexo, en especial los casos de discriminación en la prestación de servicios por establecimientos públicos; a la exención de conciencia provocada por el mandato contraceptivo de la Obamacare; a los derechos de las personas transgénero, tanto en la educación como en el ejército; a las exenciones fiscales reconocidas en los casos de planes eclesiales a efectos de la ERISA; a las ayudas económicas a centros religiosos y el alcance de las Blaine Amendments estatales; a la discriminación laboral por la orientación sexual del trabajador; al alcance de las doctrinas de abstención eclesiástica y excepción ministerial; o a la discriminación religiosa en las prohibiciones de Trump sobre inmigración. A todos estos capítulos habría que añadir los tradicionales acerca de la simbología religiosa estática (cruces y decálogos), de la conexión entre la libertad de expresión y el libre ejercicio de la religión, de las demandas de libertad religiosa bajo las dos secciones de la RLUIPA, en particular en las prisiones pero ahora también en las ordenanzas municipales que tratan de evitar la construcción de mezquitas, todo ello en el contexto permanente de una abierta guerra cultural entre posiciones secularizantes y creyentes, revitalizada ahora con la llegada de Trump a la Casa Blanca. A todas éstas habría que sumar otras cuestiones que ya se nos presentan en el horizonte como prometedoras para interesantes crónicas futuras: es el caso del compromiso del Departamento de Educación sobre la elección y bono escolar, o el deseo del presidente de revocar la Enmienda Johnson de 1954 a fin de permitir a las iglesias participar en el discurso político sin perder por ello su carácter benéfico no lucrativo.

Dejemos que la crónica de estos dos años acabe con el recuerdo agradecido del derecho español al juez Scalia y que sean sus palabras pronunciadas al

\footnotetext{
les Chaput intervino en la discusión a favor de la defensa pública de la fe y en contra del calificativo de «haters» pues a su juicio, quienes luchaban por la libertad religiosa más que «haters» eran «heroes»: Ch. J. ChAPUT, A word about useful tools, July 18, 2017, en http://catholic philly.com/2017/07/think-tank/archbishop-chaput-column/a-word-about-useful-tools/. En medio de todas estas circunstancias, la Iglesia católica fiel a Roma oscila entre quienes continúan fascinados por el Papa Francisco y quienes lo observan, desde su sometimiento, con cierta perplejidad a la espera de una respuesta a los dubia presentados por cuatro cardenales, entre ellos el estadounidense Raymond Leo Burke, sobre cuestiones doctrinales relativas a la moral en relación a la exhortación apostólica del 2016 Amoris laetitia. Con todo, a 25 de septiembre, en el grupo de los 62 católicos intelectuales de todo el mundo que presentaron al Papa una corrección formal en agosto de 2017 no figuraban muchos estadounidenses.
} 
salir del College de Georgetown el mejor epitafio a su extraordinario legado: «Debemos medir el éxito de estos (...) años, no por las partículas de verdad que hemos capturado, ya que sólo son granos de arena a lo largo de una orilla del océano, y pronto incluso éstos saldrán de nuestra memoria. Pero si, por medio de ellas, hemos aprendido a amar la verdad, el arte de hallarla, de cómo pensar, de cómo tomar una idea que yace muerta entre las páginas de un libro y hacer que viva en nuestra mente, entonces saldremos de aquí sabios, ardientes y hábiles buscadores de la verdad, saldremos de aquí hombres (...) lo que tenemos que hacer, como hombres, el deber esencial y distintivo de nuestra tribu, es continuar la búsqueda de la verdad. Este objetivo no puede cambiar nunca (...) Pensad en el gran número de hombres que nunca han oído las voces del pasado, que no saben nada de la herencia de la sabiduría humana, ¿quién de ellos comenzará esa empresa solos y totalmente sin ayuda? Lo pueden hacer pero nunca lo lograrán. Pensad en los hombres que no han escuchado la Palabra de Cristo susurrada al alma. Ellos buscan, pero no saben lo que están buscando. Ellos no están persiguiendo la verdad, sino que simplemente se agarran a su sombra. Sus ojos pueden ver sólo la base y su sombra, mientras que las alas de la verdad se despliegan alto por encima de ellos. Carecen de los ojos de la fe, la única que puede penetrar en la eternidad, y por lo tanto están condenados a perder el camino, dejar la verdad, y apagar la luz. ¿Quién queda entonces? Sólo nosotros mismos entrenados en la razón y en la fe (...) la vida intelectual, que es esencialmente la búsqueda incesante de la verdad de la que hablamos, no pertenece sólo a la universidad (...) Va mucho más allá, llega a donde quiera que haya un hombre que lo sea y se atreva a pensar. Es nuestra tarea llevar y avanzar en todos los sectores de nuestra sociedad esta vida distintivamente humana, de la razón aprendida y de la fe creída. Si no somos capaces de hacer esto, si permitimos que las preocupaciones de la riqueza o de la fama o de una carrera especializada sofoquen el espíritu de asombro, para desviarnos de la búsqueda de la verdad, para matar en nosotros lo que era más humano, entonces nos hemos traicionado a nosotros mismos, a nuestra sociedad, a nuestra raza. Si realmente amamos la verdad, creamos que se nos ha mostrado un camino maravilloso, que debemos seguir preparándonos para seguirlo, que la vida no vale la pena vivirla si no es así. El premio es grande. El riesgo es glorioso» ${ }^{105}$. Querido maestro, gracias. Descanse en paz.

105 Cfr. A. SCALIA, Cohonguroton Oration, 86 Georgetown College Journal 12-14 (Autumn 1957), también en http://www.georgetownacademy.com/blog/2016/2/21/scalias-cohonguroton. 
BIBLIOGRAFÍA

RECENSIONES 
